\title{
地球温暖化問題と課題
}

経済産業省製造産業局 紙業生活文化用品課 植 田 拓 郎

\section{Global Warming Issues with Pulp and Paper Industry in Japan}

\section{Takuro Ueda}

Paper Industry. Consumer and Recreational Goods Division. Manufacturing Industries Bureau, Ministry of Economy. Trade and Industry

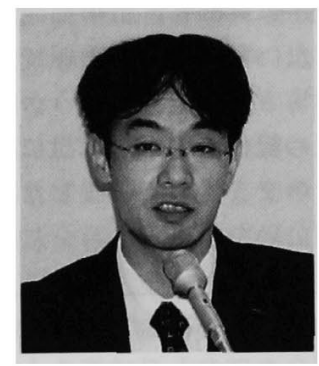

To fulfill the commitment of the Kyoto Protocol adopted in December 1997, the promotion of measures on the global warming is a critical issue in the field of pulp and paper industry, which is one of the major energy users. However, investments on environment field such as energy conservation have not been so active, because of the recent situation of overall economy and individual corporate profit. Thus, for pulp and paper industry, it is essential not only to deal with environmental issues, but also to strengthen its competitive advantages. In order to realize these, we have to fully understand situations and problems that the industry is facing. From this viewpoint, government's policy measures, current situation and issues of the industry, and the strategy for strengthening its competitiveness are discussed.

分類： $X_{1}$ 環境総論, $X_{2}$ 紙パルプ産業環境一般

1.はじめに

地球温暖化問题については国際社会で対処するため, 「気候変動に関する国際連合枠組条約（以下「気候変 動枠組条約」という。)」が 1992 年 5 月に採択され, 我が国も同年 6 月の国際連合環境開発会議において署 名, 1993 年 5 月に受諾し, 気候変動枠組条約は 1994 年 3 月に発効した。1997 年 12 月に京都で開催された 気候変動枠組条約第 3 回締約国会議（COP 3）におい て, 先進国の温室効果ガスの削減を法的拘束力を持つ ものとして約束する「京都議定書」が採択された。こ れを受けて, 1998 年 6 月に, 地球温暖化対策本部にお いて, 2010 年に向けて緊急に推進すべき地球温暖化対 策をとりまとめた「地球温暖化対策推進大網」を決定 した。2002 年 9 月にヨハネスフルク・サミット（持
続可能な開発に関する世界首脳会議) が開催されるこ とを踏まえ, 2002 年 2 月に地球温暖化対策本部を開催 し,「地球温暖化对策推進大網」を見直し新たな大網 を策定することを決定し, 2002 年 3 月に新大綱を策定 している。

\section{2. 地球温暖化問題に関する日本の課題と} 取り組み

\section{1 地球温暖化対策推進大綱の概要について}

\subsection{1 基本的考元方}

2002 年 3 月に見直しされた「地球温暖化推進大網」 の基本的な考え方は以下のとおりである。

1）温暖化対策への取り組みが, 経済活性化や雇用 創出などにもつながるよう, 技術革新や経済界の創意 工夫を活かし，環境と経済の両立に資するような仕組 
みの整備・構築を図る（「環境と経済の両立」）。

2）節目節目（2004 年, 2007 年）に対策の進渉状況 について評価・見直しを行い，段階的に必要な対策を 講じていく(「ステップ・バイ・ステップのアプロー 千」)。

3）京都議定書の目標達成は決して容易ではなく, 国, 地方公共団体, 事業者, 国民といったすべての主 体がそれぞれの役割に応じて総力を挙げて取り組むこ とが不可欠である。かかる観点から, 引き続き事業者 の自主的取り組みの推進を図るとともに，特に，民生 ・運輸部門の対策を強力に進める（「各界各層が一体 となった取り組みの推進」。

4）米国や開発途上国を含む全ての国が参加する共 通のルールが構築されるよう, 引き続き最大限の努力 を傾けていく(「地球温暖化対策の国際的連携の確保」)。

\section{1 .2 新大網のポイント}

我が国における京都議定書の約束 (2008 年から 2012 年の第 1 約束期間に 1990 年比 $\Delta 6 \%$ 削減）を履行す るための具体的裏付けのある对策の全体像を明らかに する。政府を挙げて 100 種類を超える個々の対策・施 策のパッケージをとりまとめたものである。地球温暖 化対策推進法に規定する京都議定書目標達成計画は新 大網を基硙として策定することとしている。

\6\%削隇約束については, 当面, 表 1 に示す(1) 〜5の目標により達成していくとしている。その際, (1) (5)の目標のうち, 第 1 約束期間において, 目標の 達成が十分に見込まれる場合については，こうした見 込みに甘んじることなく，引き秸き着実に対策を推進 するとともに，今後一層の排出削減を進めるものとす る。なお，国としての京都議定書上の約束達成義務及 び京都メカニスムが国内対策に対して補足的であると する原則を踏まえ，国際的動向を考虑しつつ，京都メ カニスムの活用について検討する。

地球温暖化対策推進本部は, 2004 年, 2007 年に本大 綱の内容の評価・見直しを行う。この際，本大網の前 提とした各種経済フレーム等についても必要に応じて 総合的に評価・見直しを行った上で，柔軟に対策・施 策の見直しを行う。

本大緰については,これまでの関係審議会等におけ るパプリックコメントや審議の結果等を踏まえつつ, 「関係審議会合同会竓」での意見聴取を踏まえ，その 策定作業を行ったところであるが, 京都議定書目標達 成計画の策定に当たっては，本大綱を基磁としつつ， さらに国民各界各層の意見を幅広く䦥くものとする。

表 1 に温室効果ガスについてその区分ごとの対策 （例）を示す。表 1 の(1)〜(5)を合計しても・ $6 \%$ には
ならないが, 残りの $1.6 \%$ はいわゆる京都メカニズム (共同実施 (JI) , クリーン開発メカニズム (CDM) 及 び排出量取引）の活用となるが, 国としての京都議定 書上の約束達成義務及び京都メカニズムが国内対策に 対して補足的であるという原則を踏まえ，国際的動向 を配虑しつつ, 京都メカニズムの活用について検討す るものとされている。

\section{2 産業界における地球温暖化対策の取り組み 状況}

\subsection{1 経緯及びフォローアップの方針}

地球温暖化対策への取り組み強化が求められる 中, 1997 年に経団連環境自主行動計画が策定されたこ とをはじめとして, 産業界の自主的な地球温暖化対策 が進んでいる。2002 年 3 月に改訂された地球温暖化 対策推進大網においても，「自主行動計画等により期 待される省エネルギー量は本大網における省エネルギ 一対策のおよそ 3 分の 1 の量を占め, 今後の省エネル ギー対策においても中心的役割を成すもの」であり， 「大網の中核の一つを成すもの」であると定義づけら れている。

産業構造審議会及び総合エネルギー調査会の合同小 委員会においては, 地球温暖化対策に関する産業界の 自主行動計画のフォローアップを実施している。2002 年度においても，産業界の取り組みの実効性及び外部 への透明性等を確保する観点から経団連の自主行動計 画フォローアップの結果概要が発表された 2002 年 10 月以降, 各事業者団体の自主行動計画の達成状況につ いてフォローアップを行っている。なお，HFC.PFC， SF 6 については, 2002 年 6 月に産業構造審議会化学・ ハイイオ部会において, 産業界の自主行動計画のフォロ ーアップを行った。

\subsection{2 対象業種及び進め方等}

2002 年 12 月に開催された自主行動計画小委の下に 設置した 7 つの W (鉄龬, 化学・非鉄金属, 製紙・ 板硝子・セメント等, 自動車・自動車部品, 電子・電 機・産業機械等, 資源エネルギー，流通）において, 28 の事業者団体から, 自主行動計画の目標達成に向けた 進捗状況について説明を行い，今後の進め方及び検討 課題について意見交換が行われた。なお, 経済産業省 のフォローアップへの参加業種については, 写真機製 造業が休会のためフォローアッブを行っていないが, 新たに自動車車体製造業が参加したため, 全数には変 化がない。

2002 年度は, 12 月に各WG 開催, そこでの䊩議 結果をとりまとめ 1 月に合同小委員会を開催すること で, 省内フォローアップ作業を実施している。なお, 
表 1 温室効果ガスその他区分ごとの対策（例）

(1) エネルギー起源二酸化炭素 $( \pm 0.0 \%)$

※1990 年度と同水準に抑制することを目標

\begin{tabular}{|c|c|c|c|}
\hline & 産業部門 & 民生部門 & 運輸部門 \\
\hline $\begin{array}{l}\text { 省エネ } \\
22 \text { 百万 } \mathrm{t}- \\
\mathrm{CO}_{2} \text { の追加 } \\
\text { 対策 }\end{array}$ & 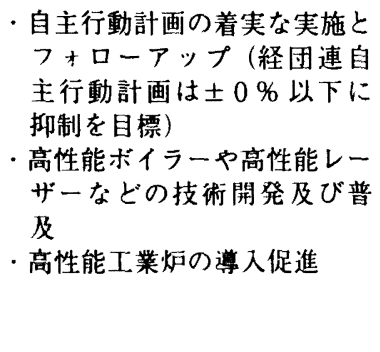 & $\begin{array}{l}\text { ·省エネ法の改正により, 大規模 } \\
\text { オフィスビ等についても, } \\
\text { 大規模工場に準ずるエネルギ } \\
\text { 一管理の仕組みを導入。 } \\
\text { ·従来対象となっていなかったガ } \\
\text { ス機器等をトップランナー適 } \\
\text { 用機器として拡大追加 } \\
\text { ·高効率給湯器の普及促進 } \\
\text { ·家庭・業務用エネルギーマネジ } \\
\text { メントシステムの普及促進 }\end{array}$ & $\begin{array}{l}\text { ・トップランナー基準適合車の } \\
\text { 加速的導入, クリーンエネ } \\
\text { ルギー自動車を含む低公害 } \\
\text { 車の開発・普及の加速等 } \\
\text { ·高度道路交通システム(ITS) } \\
\text { の促進等の交通流対策 } \\
\text { ・海運へのモーダルシフト等物 } \\
\text { 流の効率化 } \\
\text { ·公共交通機関の利用促進 }\end{array}$ \\
\hline $\begin{array}{l}\text { 新エネ } \\
34 \text { 百万 } \mathrm{t}^{-} \\
\mathrm{CO}_{2} \text { の追加 } \\
\text { 対策 }\end{array}$ & \multicolumn{3}{|c|}{ 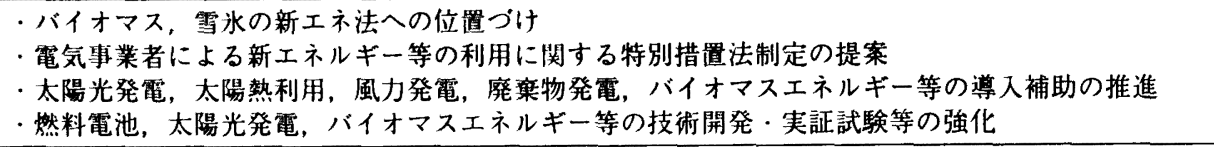 } \\
\hline $\begin{array}{l}\text { 燃料転換等 } \\
18 \text { 百万 } \\
\mathrm{CO}_{2} \text { の追加対策 }\end{array}$ & \multicolumn{3}{|c|}{$\begin{array}{l}\cdot \text { 老朽石炭火力発電の天然ガスへの転換支援 } \\
\text { ・産業用ボイラー等の燃料転換支援 } \\
\text { ·灭然ガスパイブラインにかかる安全基準の整備 }\end{array}$} \\
\hline $\begin{array}{l}\text { 原子力の } \\
\text { 推進 }\end{array}$ & \multicolumn{3}{|c|}{$\begin{array}{l}\text { 安全性の確保を大前提とした原子力の推進 } \\
\text { 核燃料サイクル施設等の立地に係る電源立地地域振興策の推進 }\end{array}$} \\
\hline (注) & 約 462 百万 $\mathrm{t}-\mathrm{CO}_{2}(\boldsymbol{\Delta} \%)$ & 約 260 百万 $\mathrm{t}-\mathrm{CO}_{2}(\Delta 2 \%)$ & 約 250 百万 $\mathrm{t}-\mathrm{CO}_{2}(+17 \%)$ \\
\hline
\end{tabular}

(注)（）内は, 1990 年度の各部門別の排出量からの削堿割合。

※部門毎の排出削減目標量については, 様々な条件や前提の下に達成することができると試算される目安として設定 するもの。

※対策の評価は，エネルギー需給構造全体の観点に立って一定の幅をもって行うべきもの。

※事業者等による京都メカニスムの活用も認められており，自らの削減をより费用効果的に達成するために活用され ることが期待。

(2) 非エネルキー起源二酸化炭素,メタン, 一酸化二窒素 $(\Delta 0.5 \%)$ ※0.5\% 分の削減を達成することを目標

\begin{tabular}{|c|c|c|}
\hline $\begin{array}{l}\text { 非エネルギー起源 } \\
\text { 二酸化炭素 }\end{array}$ & \multicolumn{2}{|r|}{ 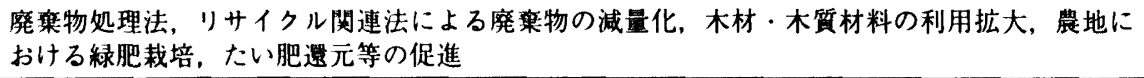 } \\
\hline メタン & \multicolumn{2}{|c|}{$\begin{array}{l}\text { 食品リサイクル法等による廃乗物の直接埋立の半減 } \\
\text { ほ場の管理の改善 } \\
\text { 農業部門からの排出削減技術開発 }\end{array}$} \\
\hline 一酸化二窒素 & \multicolumn{2}{|c|}{ 下水道施設計画などによる下水污泥の燃烧の高度化 } \\
\hline \multicolumn{3}{|c|}{$\begin{array}{l}\text { (3) 革新的技術開発及び国民各界各層の更なる地球温暖化防止活動の推進（山2.0\%） } \\
\ldots 2.0 \% \text { 分の削減を達成することを目標 }\end{array}$} \\
\hline \multicolumn{2}{|l|}{ 革新的技術開発 } & $\begin{array}{l}\text { 省エネ型新製鉄プロセス，省エネ型新規化学プロセス，自動車軽量化用材料開発，低消 } \\
\text { 费電力型電子機器，低電力損失送配電システム等の研究開発を実施 } \\
\end{array}$ \\
\hline \multicolumn{2}{|c|}{$\begin{array}{l}\text { 国民各界各層の更なる地球 } \\
\text { 温暖化防止活動の推進 }\end{array}$} & $\begin{array}{l}\text { 白熱灯の電球形蛍光灯への取り換え, 夜間屋外照明の上方光束のカット, 冷藏庫の効率 } \\
\text { 的使用, 節水シャワーヘッドの導入, 事務所の一旦消灯, 無駄なコピーの縮隇等 }\end{array}$ \\
\hline \multicolumn{3}{|c|}{$\begin{array}{l}\text { (4) 代替フロン等 } 3 \text { ガス (HFC, PFC, SF 6) (+2.0\%) } \\
\text { ※自然体でプラス } 5 \% \text { をブラス } 2 \% \text { 程度の影響に止めることを目標 }\end{array}$} \\
\hline \multicolumn{3}{|c|}{$\begin{array}{l}\text { 産業界の行動計画のフォローアップ } \\
\text { 新規代替物質の開発等の技術開発 } \\
\text { 家電リサイクル法, フロン回収破嗉法の適切な運用 }\end{array}$} \\
\hline \multicolumn{3}{|c|}{$\begin{array}{l}\text { (5) 吸収量の確保 }(\boldsymbol{\Delta} 3.9 \%) \\
\text { ※COP } 7 \text { で合意された } 3.9 \% \text { 程度の吸収量の確保を目標 }\end{array}$} \\
\hline \multicolumn{3}{|c|}{ 植栽, 下刈, 間伐等の健全な森林の整備, 木材・木所ハイイォス利用の促進, 都市緑化等の推進 } \\
\hline
\end{tabular}


表 2 エネルギー消費量, $\mathrm{CO}_{2}$ 排出実績及び見通し

\begin{tabular}{|c|c|c|c|c|c|c|c|}
\hline & 1990 年 & 1998 年度 & 1999 年度 & 2000 年度 & 2001 年度 & $\begin{array}{l}2005 \text { 年 } \\
\text { (見通し) }\end{array}$ & $\begin{array}{l}2010 \text { 年 } \\
\text { (見通し) }\end{array}$ \\
\hline $\begin{array}{l}\text { 生産量 } \\
\text { (千トン) }\end{array}$ & $\begin{array}{r}28,086 \\
(100.0)\end{array}$ & $\begin{array}{c}29,798 \\
(106.1)\end{array}$ & $\begin{array}{r}31,027 \\
(110.5) \\
\end{array}$ & $\begin{array}{r}31,742 \\
(113.0) \\
\end{array}$ & $\begin{array}{r}30,352 \\
(108.1) \\
\end{array}$ & $\begin{array}{r}34,600 \\
(123.2) \\
\end{array}$ & $\begin{array}{r}36,900 \\
(131.4) \\
\end{array}$ \\
\hline $\begin{array}{l}\text { 化石エネルギー消費量 } \\
\text { (TJ) }\end{array}$ & $\begin{array}{r}414,674 \\
(100.0) \\
\end{array}$ & $\begin{array}{l}422,887 \\
(102.0) \\
\end{array}$ & $\begin{array}{l}427,079 \\
(103.0)\end{array}$ & $\begin{array}{l}432,380 \\
(104.3) \\
\end{array}$ & $\begin{array}{l}415,395 \\
(100.2)\end{array}$ & $\begin{array}{l}466,649 \\
(112.5) \\
\end{array}$ & $\begin{array}{l}490,331 \\
(118.2) \\
\end{array}$ \\
\hline $\begin{array}{l}\text { 化石エネルギー消費量 } \\
\text { (原油 } \mathrm{OE} \text { 換算千 } \mathrm{k} l \text { ) }\end{array}$ & $\begin{array}{r}10,709 \\
(100.0) \\
\end{array}$ & $\begin{array}{r}10,921 \\
(102.0) \\
\end{array}$ & $\begin{array}{r}11,030 \\
(103.0)\end{array}$ & $\begin{array}{r}11,167 \\
(104.3)\end{array}$ & $\begin{array}{r}10,728 \\
(100.2) \\
\end{array}$ & $\begin{array}{r}12,052 \\
(112.5) \\
\end{array}$ & $\begin{array}{r}12,663 \\
(118.2) \\
\end{array}$ \\
\hline $\begin{array}{l}\mathrm{CO}_{2} \text { 排出量 } \\
\left(\text { 千 }-\mathrm{CO}_{2}\right)\end{array}$ & $\begin{array}{r}28,267 \\
(100.0)\end{array}$ & $\begin{array}{r}29,087 \\
(102.9)\end{array}$ & $\begin{array}{r}29,493 \\
(104.3)\end{array}$ & $\begin{array}{c}30,275 \\
(107.1)\end{array}$ & $\begin{array}{r}29,340 \\
(103.8)\end{array}$ & $\begin{array}{r}32,747 \\
(115.9)\end{array}$ & $\begin{array}{r}34,159 \\
(120.8)\end{array}$ \\
\hline $\begin{array}{l}\text { 化石エネルギー原単位 } \\
(\mathrm{MJ} / \text { 生産 } \mathrm{t})\end{array}$ & $\begin{array}{r}14,765 \\
(100.0)\end{array}$ & $\begin{array}{l}14,192 \\
(96.1)\end{array}$ & $\begin{array}{l}13,765 \\
(93.2)\end{array}$ & $\begin{array}{l}13,622 \\
(92.3)\end{array}$ & $\begin{array}{l}13,686 \\
(92.7)\end{array}$ & $\begin{array}{l}13,487 \\
(91.3)\end{array}$ & $\begin{array}{r}13,288 \\
※(90.0)\end{array}$ \\
\hline $\begin{array}{l}\text { 化石エネルギー原単位 } \\
\text { (原油 } \mathrm{OE} \text { 換算 } l \text { 生産 } \mathrm{t} \text { ) }\end{array}$ & $\begin{array}{r}381 \\
(100.0)\end{array}$ & $\begin{array}{r}367 \\
(96.1)\end{array}$ & $\begin{array}{r}356 \\
(93.2)\end{array}$ & $\begin{array}{r}352 \\
(92.3)\end{array}$ & $\begin{array}{r}353 \\
(92.7)\end{array}$ & $\begin{array}{r}348 \\
(91.3)\end{array}$ & $\begin{array}{r}343 \\
(90.0)\end{array}$ \\
\hline $\begin{array}{l}\mathrm{CO}_{2} \text { 排出原単位 } \\
\left(\mathrm{t}-\mathrm{CO}_{2} \text { 生産 } \mathrm{t}\right)\end{array}$ & $\begin{array}{r}1.006 \\
(100.0)\end{array}$ & $\begin{array}{r}0.976 \\
(97.0)\end{array}$ & $\begin{array}{r}0.951 \\
(94.4)\end{array}$ & $\begin{array}{r}0.954 \\
(94.8)\end{array}$ & $\begin{array}{r}0.967 \\
(96.0)\end{array}$ & $\begin{array}{r}0.946 \\
(94.0)\end{array}$ & $\begin{array}{r}0.926 \\
(92.0)\end{array}$ \\
\hline
\end{tabular}

注）（）は1990 年を基準とした指数

$\mathrm{TJ}=10$ の 12 乗ジュール, MJ=10の 6 乗ジュール

原油換算は $\mathrm{OE}$ (Oil Equivalent $38.72 \mathrm{MJ} /=9,250 \mathrm{kcal} / l$

※2010 年は目標を達成したものとして試算

経団連は 10 月に 2001 年度のフォローアップの結果概 要を公表している。

\section{3 製紙産業における地球温暖化対策の取り組み}

製紙産業の地球温暖化対策に関する取り組みの概要 についてのべる。

業界の自主行動計画における目標は，1省エネルギ 一の推進(2010年までに製品当り化石エネルギー原 単位を 1990 年比 $10 \%$ 削隇)，2古秖利用の促進（ご み減量化, 省エネルギー, 森林資源の保全の観点から 古紙の回収・利用の促進を図るため, 2005 年度までに 古紙利用率 $60 \%$ を達成), (3)植林事業の㹡大（国内外 における植林事業の推進に努め, 2010 年までに所有ま たは管理する植林地を 55 万へクタールに搪大) とな っている。

表 2 は 2002 年度ワーキンククループの資料である 化石エネルギー原単位の実績の推移と今後の見通しが 示されている。化石エネルギー原単位を2010年に 1990 年比 $90 \%$ とする目標に対して, 2001 年度で $92.7 \%$ となっており，着実に削減してきている。

表 3 は 2001 年度までの各業種のエネルギー起源 $\mathrm{CO}_{2}$ 排出量の実績と 2010 年度目標又は見通しを示す。

\section{3. 我が国紙パルプ産業の課題と展望}

\section{1 我が国紙・パルプ産業の現状}

紙・パルプ産業は，産業活動と国民生活に不可欠な 素材である紙・板紙を供給する重要な役割を担う基盤 産業であり，我が国経済・国民生活とともに発展して きた。

我が国紙・パルフ産業は, 出荷額約 8 兆円, 従業員 数約 25 万人の规模にあり，製造業の中では出荷額・ 従業貝数ともに約 $3 \%$ を占める産業規模となってい る(国内主要企業：王子製紙，日本ユニパックホール ディンク, 大王製紙, レンコー, 三菱製紙, 北越製紙 等)。

\section{2 我が国紙・パルプ産業の概況}

我が国紙パルブ産業の 2001 年の出荷額は, 約 8 兆 円（製造業の約 $2.6 \%$, 紙・パルブ製造業のみでは約 3 兆円), 従業只数は約 25 万人 (製造業の約 $2.6 \%$ ), 紙・板紙生産量は, 2000 年 $: 3,183$ 万卜ン, 2002 年： 3,069 万卜ン。板紙貿易量（2002 年）は, 輸出：158 万トン（対生産量： $5.1 \%$ ), 輸入 : 152 万トン（対内 需量： $4.9 \%$ ）となっている。 


植田拓郎

表 3 各業種のエネルギー起源 $\mathrm{CO}_{2}$ 排出量実績等

(単位: 万 $\mathrm{t}-\mathrm{CO}_{2}$ )

\begin{tabular}{|c|c|c|c|c|c|c|c|}
\hline & $\begin{array}{l}1990 \text { 年度 } \\
\text { (実績値) }\end{array}$ & $\begin{array}{l}1999 \text { 年度 } \\
\text { (実績值) }\end{array}$ & $\begin{array}{l}2000 \text { 年度 } \\
\text { (実績値) }\end{array}$ & $\begin{array}{l}2001 \text { 年度 } \\
\text { (実績値) }\end{array}$ & $\begin{array}{l}2010 \text { 年度 } \\
\text { (日程又は } \\
\text { 見通し) }\end{array}$ & $\begin{array}{c}\text { 業種内 } \\
\text { カバー率 }\end{array}$ & $\begin{array}{l}\text { 情報公 } \\
\text { 開対応 }\end{array}$ \\
\hline 鉄鋼業 & $19,501.60$ & $18,888.60$ & $18,244.70$ & $17,811.90$ & $17,746.40$ & $100 \%$ & (a) \\
\hline 自動車 & 759 & 641 & 625 & 585 & 642 & $100 \%$ & (2) \\
\hline 自動車部品 & 823.9 & 811 & 779 & 710.1 & 766.2 & $61 \%$ & (9) \\
\hline 自動車車体 & 92.9 & 84.8 & 89.5 & 90 & 75.5 & $90 \%$ & (a) \\
\hline 製紙業 & $2,826.7$ & $2,949.3$ & $3,027.5$ & 2,934 & $3,415.9$ & $100 \%$ & () \\
\hline セメント業 & $2,747.7$ & $2,466.6$ & 2,476 & $2,377.70$ & $3,185.1$ & $100 \%$ & (C) \\
\hline 板硝子業 & 178.4 & 137.9 & 134.7 & 137.5 & 149.8 & $100 \%$ & (0) \\
\hline 染色整理業 & 391.4 & 311.1 & 298.2 & 280.3 & 250.7 & $100 \%$ & $\Delta$ \\
\hline ガラス容器業 & 181.2 & 126.7 & 123.3 & 122.7 & 142.9 & $90 \%$ & () \\
\hline 非鉄製錬業 & 488.4 & 494.9 & 505.7 & 503.5 & 533.1 & $100 \%$ & 0 \\
\hline 石灰石鉱業 & 47.96 & 42.32 & 43.8 & 43.3 & 47.64 & $86 \%$ & 0 \\
\hline 石炭鉱業 & 58.5 & 18.7 & 18.9 & 15.3 & 3.3 & $100 \%$ & $\mathrm{O}$ \\
\hline 石油精製業 & 3,387 & 4,374 & 4,350 & 4,379 & 4,356 & $100 \%$ & (2) \\
\hline 電気事業（固有分） & 3,110 & 3,360 & 3,430 & 3,370 & 3,640 & $100 \%$ & (2) \\
\hline 都市ガス業 & 116 & 89 & 84 & 77 & 73 & $100 \%$ & (2) \\
\hline 電機・電子業 & $1,179.8$ & $1,400.8$ & $1,464.5$ & $1,401.9$ & 1,046 & $80 \%$ & (0) \\
\hline 産業機械業 & - & 63.9 & 65.7 & 62.8 & 65.8 & $91.2 \%$ & (0) \\
\hline ベアリンクエ業 & - & 69 & 74.7 & 68.1 & 58.5 & $99.7 \%$ & (2) \\
\hline 工作機械業 & - & 20.1 & 20.7 & 19.5 & 18.6 & $90 \%$ & (0) \\
\hline 建設機械業 & 34.1 & 23.2 & 23.4 & 24.1 & 18.7 & $90 \%$ & (2) \\
\hline 化学工業 & $7,069.3$ & $7,811.7$ & $7,862.5$ & $7,476.1$ & $7,587.2$ & $90 \%$ & (O) \\
\hline コム製品製造業 & 192.9 & 189.9 & 184.7 & 179 & 192.9 & $80 \%$ & (2) \\
\hline アルミニウム圧延業 & 148.7 & 161.2 & 163.3 & 155.1 & 162.1 & $57.6 \%$ & (a) \\
\hline 電線業 & 109.8 & 95.6 & 101.6 & 94.5 & 87.2 & $80 \%$ & (a) \\
\hline 伸銅業 & 98.4 & 78.1 & 81.4 & 67.8 & 58.5 & $67 \%$ & $\mathrm{O}$ \\
\hline 百貨店業 & 101.75 & 169.8 & 180.6 & - & - & $74 \%$ & $\mathrm{O}$ \\
\hline チェーンストア業 & - & 376.3 & 448.8 & - & 一 & $62 \%$ & $\Delta$ \\
\hline コンビニエンスストア業 & 82.3 & 177.9 & 190.4 & 229.7 & 二 & $99 \%$ & $\triangle$ \\
\hline & 1990 年度 & 1999 年度 & 2000 年度 & 2001 年度 & \multicolumn{3}{|l|}{2010 年度 } \\
\hline $\mathrm{CO}_{\varepsilon}$ 排出総量 & $\langle 43,727.71\rangle$ & $45,433.42$ & $45,092.60$ & $43,215.90$ & \multicolumn{3}{|l|}{$\langle 44,323.04\rangle$} \\
\hline $\begin{array}{l}\mathrm{CO}_{2} \text { 排出総量 } \\
\text { (全年度分の数值が揃っ } \\
\text { た業種のみ) }\end{array}$ & $\begin{array}{r}43,543.66 \\
(100 \%)\end{array}$ & $\begin{array}{l}44,556.42 \\
(102.3 \%)\end{array}$ & $\begin{array}{r}44,111.7 \\
(101.3 \%)\end{array}$ & $\begin{array}{l}42,835.8 \\
(98.3 \%)\end{array}$ & \multicolumn{3}{|l|}{$\begin{array}{l}43,910.14 \\
(100.8 \%)\end{array}$} \\
\hline
\end{tabular}

注：カバー率は原則， $\mathrm{CO}_{2}$ 排出総量ベース。但し，以下の業種については別の指標を使用

生産量：アルミ，伸銅，石灰石生産額：電線, 産業機械, ベアリング, 工作機械

売上額：自動車部品, 自動車車体 店舗数：百貨店, コンビニエンスストア 延床面積：チェーンストア

エネルギー消費量：非鉄製鍊，建設機械，染色整理，電機・電子 新ゴム消費量：ゴム製品

注：(9)=業界独自の情報公開を行っている業種， $\mathrm{O}=$ 経団連を通じて情報公開を行っている業種

$\triangle=$ 経済産業省フォローアップのみを通じて情報公開を行っている業種 


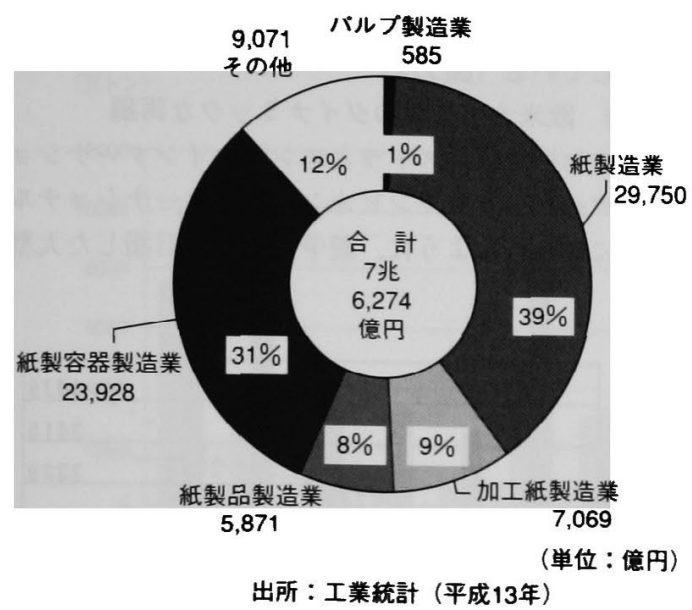

図 1 出荷額の構成（2001 年）

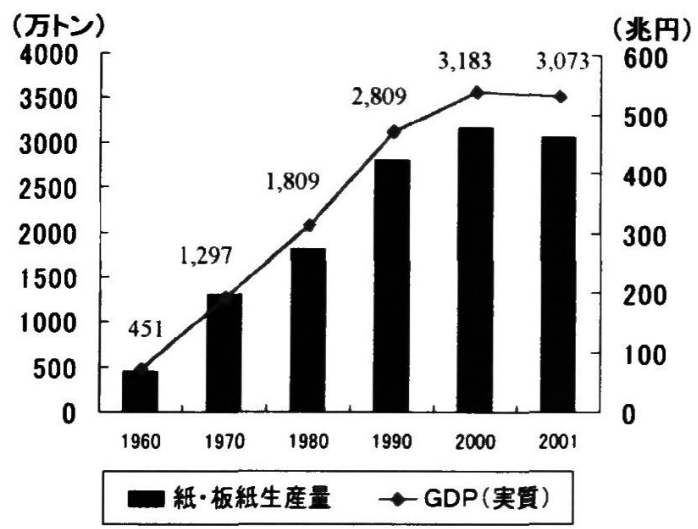

図 2 紙・板秖の生産量と GDP の推移 最近 10 年間の GDP 弾性值は 1.07

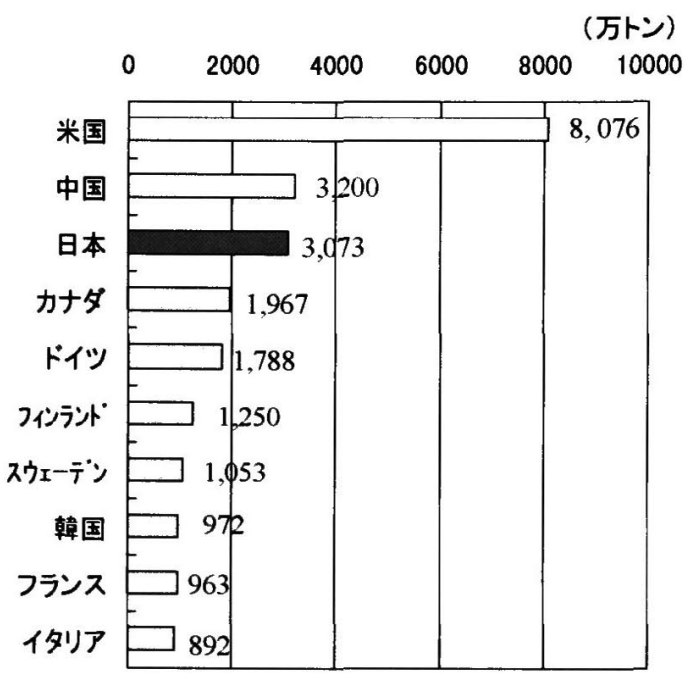

図 3 世界の紙・板紙の生産量（2001 年）

図 1 に我が国の紙パルブ産業の出荷額の構成を示す。 我が国紙・パルプ産業は, 国内紙・板紙需要の堅調な 伸びを背景に，これまで概ね安定的な発展を遂げてき た。我が国紙・板紙の需要量の GDP 弾性值は, 過去, 1 に近い数值となっており，我が国経済の成長とともに 秖・パルプ産業も発展してきた。

我が国紙・板紙の生産量は, 2001 年で 3,073 万トン と, 米国 ( 8,076 万トン), 中国 (3,340万トン) に次 いで世界第 3 位の規模を搉している（図 2, 図 3)。我 が国紙・パルブ産業は，優れた操業技術，古紙利用・ 環境保全技術等により，幅広い需要分野に年間約 3 千

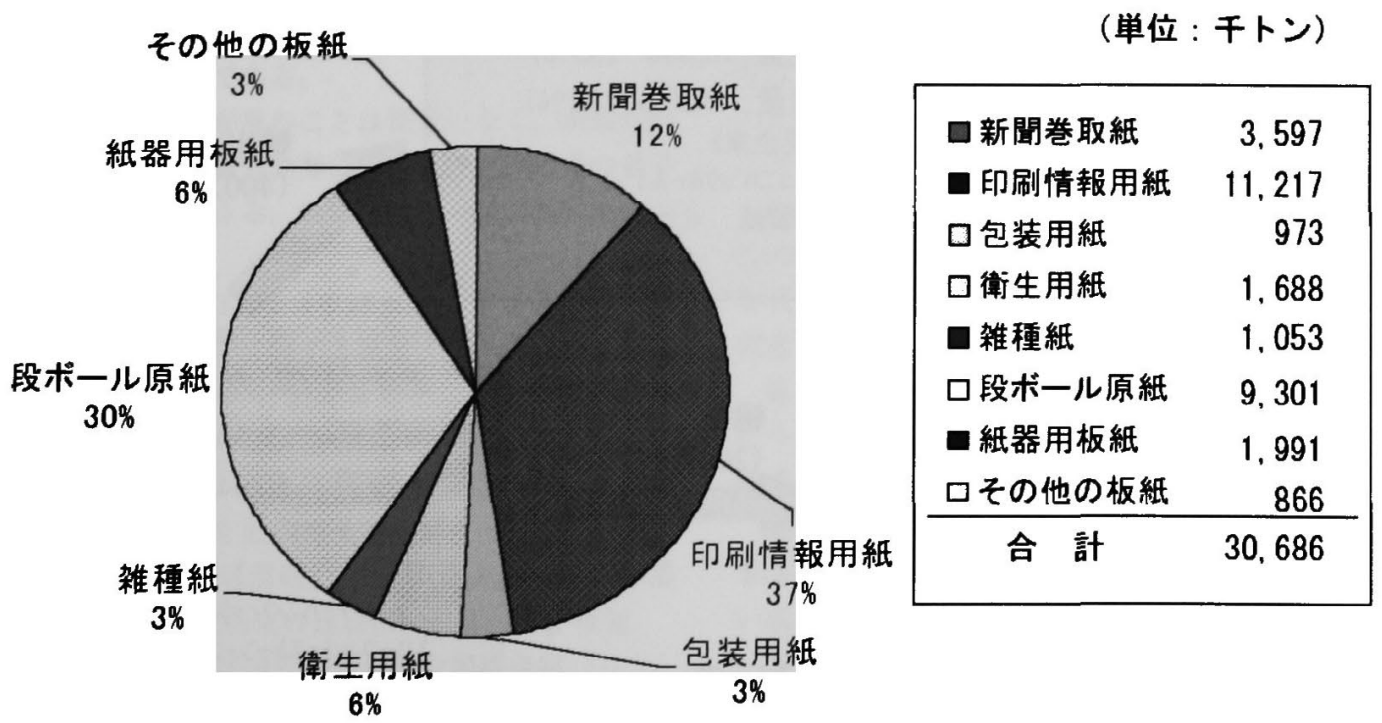

図 4 品種別生産量と主な用途（平成 14 年) 
万トンの高品質の紙・板紙を供給している。

生産量 3,069 万トンの内訳は, 洋紙が 1,853 万トン $(60 \%)$ ，板紙 1,216万トン（40\%）である（図 4)。

\section{3 紙・パルプ産業を取り巻く環境変化}

3.3.1 わが国経済と紙・板紙需要の低成長化

今後の紙・板紙需要は低成長時代へとその需要環境 が大きく変化。わが国の紙・板紙需要は, 経済成長と の相関が高く，経済成長の鈍化とともにその伸び率も 鈍化してきている。

ユーザー産業の海外移転の活発化や情報化の進展に よる電子媒体の普及等の需要への影隌の可能性があり, このため, 今後の紙・板紙需要の大幅な増加は見込め ない状況にある（図 5)。

\subsection{2 アジアでの紙・板紙市場の拡大}

世界の紙・板紙需要は, 2001 年で約 3 億 2 千万トン であり，市場は北米，欧州，アジアの3極に分けられ る。

北米，欧州の紙・板紙市場は成熟しており，大きな 需要增は見込めない状況。他方，アジア経済の発展に 伴い, アジア地域の紙・板紙需要の拡大が著しい (図 6)。

紙の生産・消費におけるアジアの地位が急激に上昇 中。特に、需要面においては，中国及びアセアンの伸 びは著しく、年率 $10 \%$ 以上を記録。欧米企業のアジ ア進出も活発化。

供給面においては, インドネシアの生産量, 輸出量 が急拡大。PPC 用紙の対日輸出が急增し,こうした
汎用品については，アジアからの輸入による競争圧力 が上昇している（図7）。

\subsection{3 欧米大手企業のダイナミックな再編}

欧米においては，ストラとエンソ，インターナショ ナル・ペーパーとチャンピオン・インターナショナル の合併に見られるように，競争力強化を目指した大型

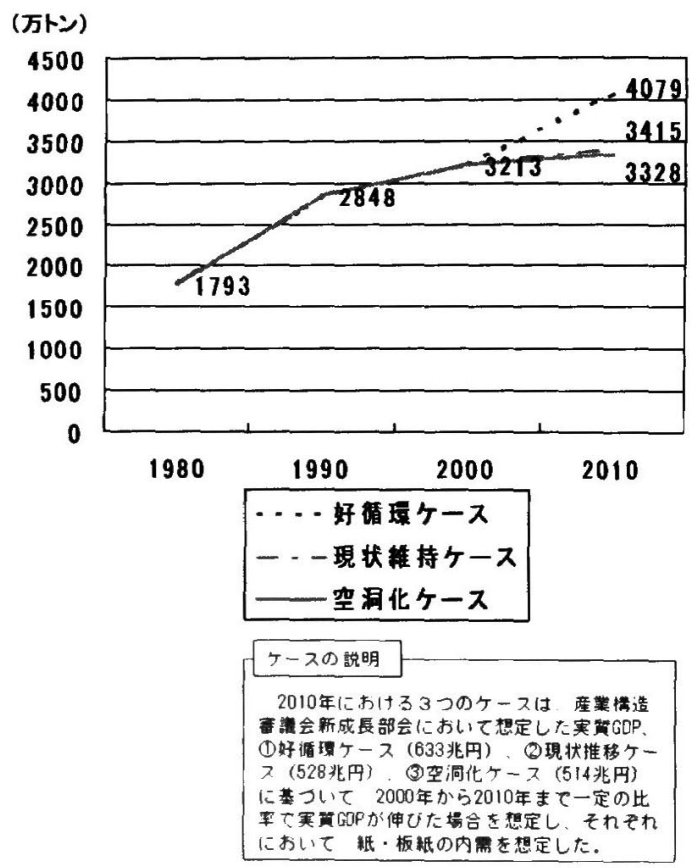

図 5 紙・板紙の需要見通し

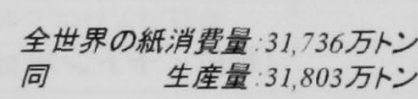

直接投資 輸出 (200万トン)

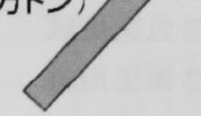

\section{欧州 (41ケ国)}

消費量：8,973 (28\%)

生産量： $9,814(31 \%)$

《主要企業》

자ラ・エンリ $13.1 \%$

UPMキュンメネ $8.4 \%$
(注) 1)消費量、生産量の( )内は世界全体に占めるシェア

アジア(40ケ国)

消費量: 10,488 (33\%) 生産量：9,766（31\%） 《主要企業》 日本ユニパックホールデイグ $8.2 \%$ 王子製紙 $6.2 \%$ APP $5.0 \%$

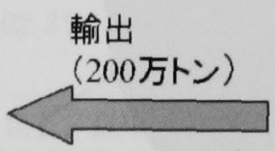
2)主要企業生産量は連結ベース、比率は域内シェア

\section{北米 (米国、カナダ)}

消費量： 9,515 (30\%)

生産量： $10,045(32 \%)$ 《主要企業》

IP

$15.5 \%$

ジョージア・パシフィク $13.7 \%$ スマーフィット・ストーン・コンデナ $8.4 \%$

図 6 世界の紙市場と域外貿易（2001 年） 

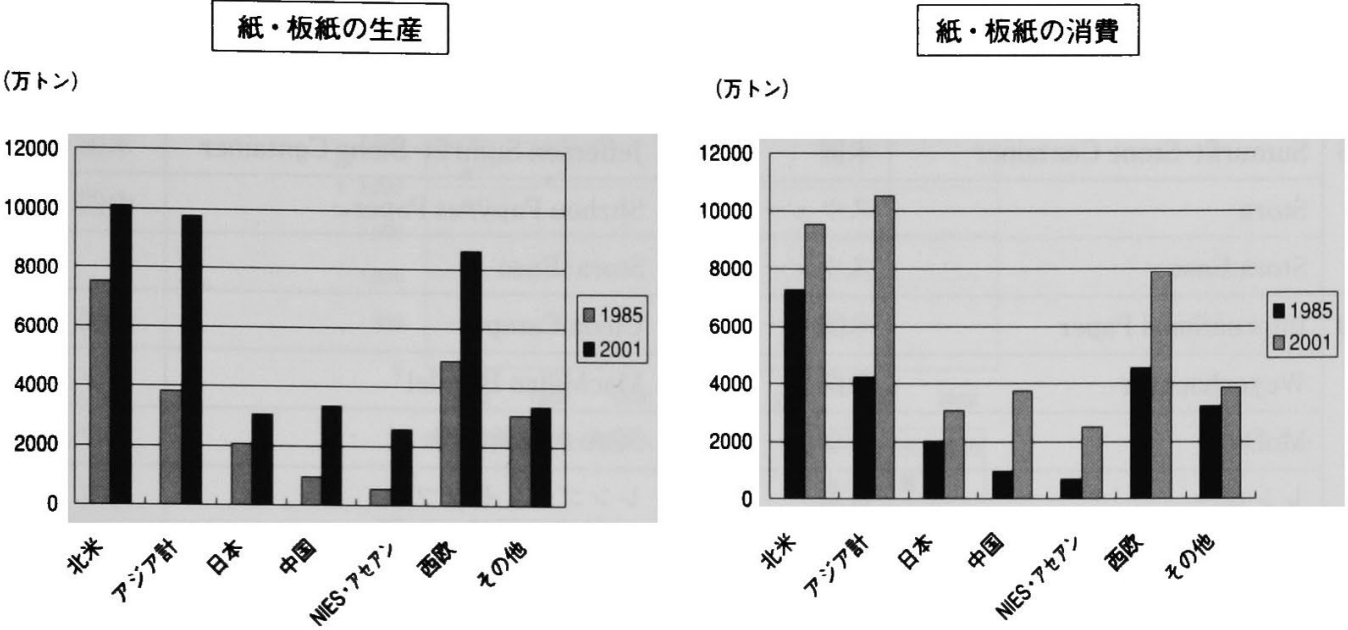

図 7 秖・板紙の生産と消費

合併，集約化が急速に進みつつある。

欧米大手企業は，こうした合併・統合により経営資 源を確保し，「選択と集中」を進めることによって， 経営資源をコアビジネスに投入し競争力強化を実現。 需要の低成長時代に高収益を確保する戦略に腐心して いる。

これまで我が国紙・パルプ産業はドメスティックな 競争を展開してきたが，欧米大手企業のアジア進出が 始まっている中, 今後, 欧米大手企業との直接的な競 争が始まるとも言える（表 4)。

\subsection{4 環境問題への対応の要請の高まり}

地球環境問題や循環型社会の構築に向けた取り組み が求められる中，エネルギー多消費型産業である紙・ パルブ産業は, 省エネ対策の実施や古紙リサイクルの 推進が重要な課題である。

㻴境制約の強化が進むことは間違いなく，環境問題 への取り組みは，海外企業に対する我が国企業の競争 力の基盤ともなりうる。地球温暖化対策の動向を以下 に示す。

・ 2001 年 11 月 COP 7 (モロッコ・マラケシュ) に おいて京都議定書に関する運用ルール等につき合意。 ・ 2002 年 2 月 フッシュ大統領が, 新たな提案（経 済成長を重視した $\mathrm{CO}_{2}$ 削減等）を発表

- 2002 年 3 月 EU 環境相理事会が開催され, 京都議 定書の批准方針を正式に決定

- 2002 年 3 月 地球温暖化対策推進大網（～京都議 定書の $6 \%$ 削減約束の達成に向けて〜）が決定

- 2002 年 6 月 京都議定書の締結を閣議决定

・ 2002 年 10 月 COP 8 (インド・ニューテ゚リー) に おいて, 京都議定書の批准を未批准国に強く促すこ
と, 地球全体の排出削隇が必要であること等を内容 とするデリー宣言が採択 - 2003 年 5 月 20 日現在 109 ヶ国が批准。全附属書

I 国の総排出量の $43.9 \%$

(参考) 京都議定書の発効要件

(1) 55 ヶ国以上が批准すること。

(2) 批准した附属書 I 国（先進国）の1990年にお ける $\mathrm{CO}_{2}$ 排出量の合計が, 全附属書 I 国の総排出量 の $55 \%$ 以上を占めること。

\section{4. 紙・パルプ産業の競争力の評価と課題}

\section{1 生産設備・コスト・品質等の状況}

我が国紙・パルプ産業における平均設備能力は, 海 外企業の水準と比較しても小規模で高齢な設備が多く なっており，生産効率という観点から劣っている。こ のため，設備の効率化を進め，生産効率の向上を図る ことが重要な課題である（図 8)。

2002 年時点でのわが国全体の生産能力は, 紙で 2, 038 万トン，板紙で 1,383 万トンである。また, 90 年代を通じての平均稼働率は，紙，板紙ともに $90 \%$ 程度である。

紙・板紙とも総じて生産能力の過剩感が強く, とく に今後の需要の増大が見込まれない板紙については過 剩感がより大いと言える（図 9)。

過去 10 年間の紙・パルプ企業の営業利益率の推移 をみると，高い稼働率を維持している時期は，概ね高 い収益率を達成している。

こうした数値等から，紙についての稼働率の適正な 水準は, 紙については, $93 \%$ 程度であり, また, 板紙 については, 93\%を超える水準と考えられる（図 10）。 


\begin{tabular}{lll} 
植田拓郎 \\
\hline
\end{tabular}

表 4 主な世界の大型合併・統合

\begin{tabular}{|c|c|c|c|c|}
\hline 年 & 買収 · 存続企業 & 本社所在国 & 非買収企業等 & 所在国 \\
\hline \multirow[t]{3}{*}{98} & Sumurfit-Stone Container & 米国 & Jefferson Sumrfit $\cdot$ Stone Container & 米国 \\
\hline & Stora & スウェーデン & Shzhou Papyrus Paper & 中国 \\
\hline & Stora Enso & スウェーデン & Stora $\cdot$ Enso & - \\
\hline \multirow[t]{4}{*}{99} & International Paper & 米国 & Union Camp & 米国 \\
\hline & Weyerhaeuser & 米国 & MacMillan Bloedel & カナダ \\
\hline & MoDo & スウェーデン & SCA 上級紙部門 & スウェーデン \\
\hline & レンゴー & 日本 & レンゴー・セッッ & 日本 \\
\hline \multirow[t]{10}{*}{00} & Abitibi-Consolidated & 米国 & Canadian Donohue & カナダ \\
\hline & Stora Enso & $\begin{array}{l}\text { スウェーデン/ } \\
\text { フィンランド }\end{array}$ & Consolidated Papers & 米国 \\
\hline & International Paper & 米国 & Shorewood Packaging & 米国 \\
\hline & Sumurfit-Stone Container & 米国 & St. Laurent Paperboard & カナタ \\
\hline & Portucel Industrial & ポルトガル & Papeis Inapa & ポルトガル \\
\hline & UPM-Kymmene & フィンランド & Repap Enterprises & カナダ \\
\hline & UPM-Kymmene & フィンランド & Changshu mill & 中国 \\
\hline & Metsa-Serla & フィンランド & MoDo Paper & スウェーデン \\
\hline & Metsa-Serla & フィンランド & Zanders FeinPapiere & ドイツ \\
\hline & Georgia Pacific & 米国 & Fort James & 米国 \\
\hline \multirow[t]{2}{*}{01} & 日本ユニパックホールディング & 日本 & 日本製紙・大昭和製紙 & 日本 \\
\hline & UPM-Kymmene & フィンランド & Haindl'sche Papierfabriken KGaA & ドイッ \\
\hline \multirow[t]{2}{*}{02} & Weyerhaeuser & 米国 & Willamette & 米国 \\
\hline & MeadWestvaco & 米国 & Mead· Westvaco & 米国 \\
\hline
\end{tabular}

出典：野村證券金融研究所

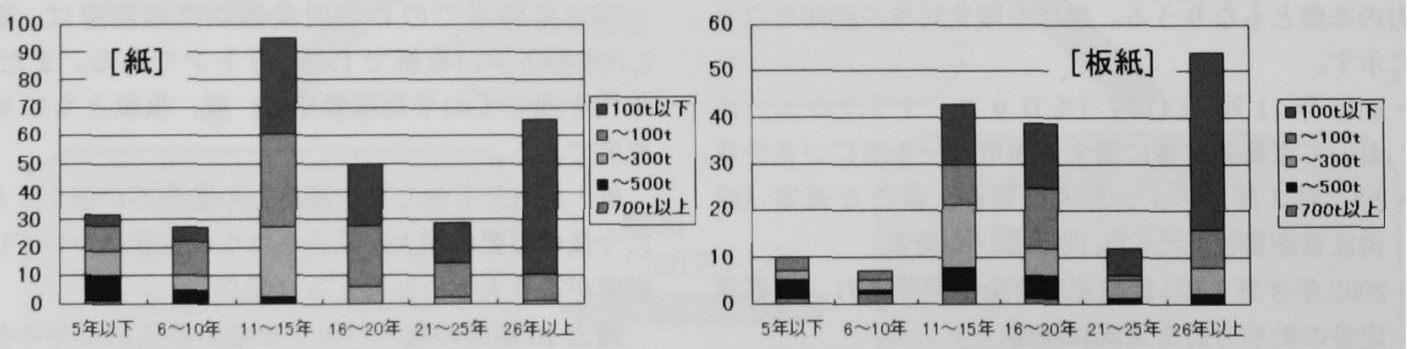

図 8 紙・板紙の抄紙機 年齢別台数

わが国紙・パルプ企業の経営状況を見ると，欧米大 手企業と比較した場合においては, ROA 等の経営指 標の水準は低く，わが国の生産設備の効率等が低いこ
とが伺える。

設備投資等の判断基準に関しては，資本コスト（加 重平均資本コスト）を上回るリターンを得ることをそ 


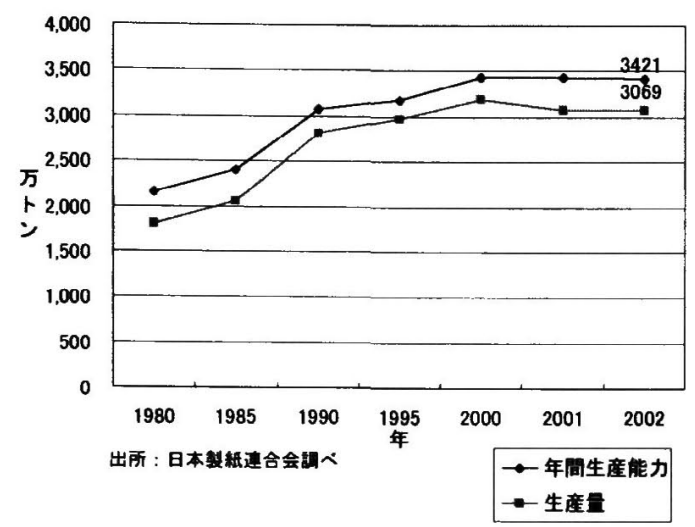

図 9 年間生産能力（推計）と生産量の推移
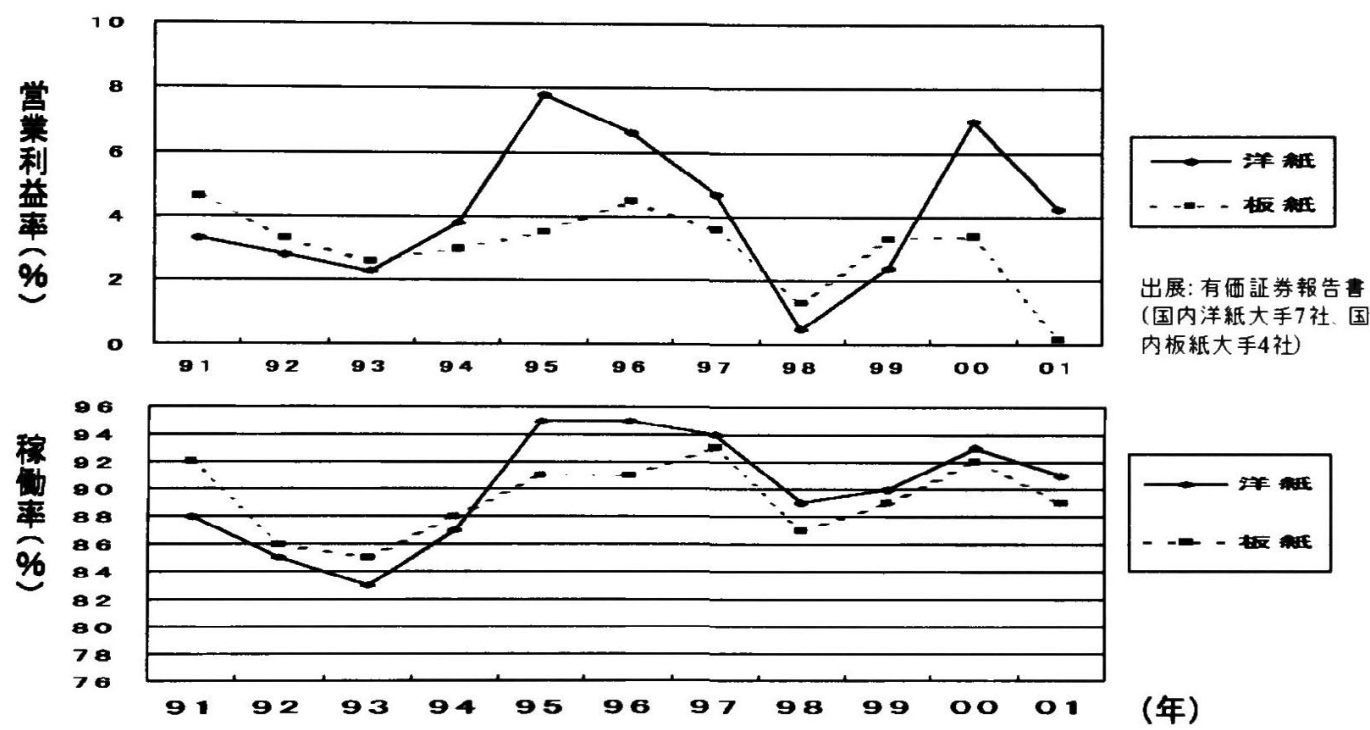

図 10 営業利益率と稼働率の推移

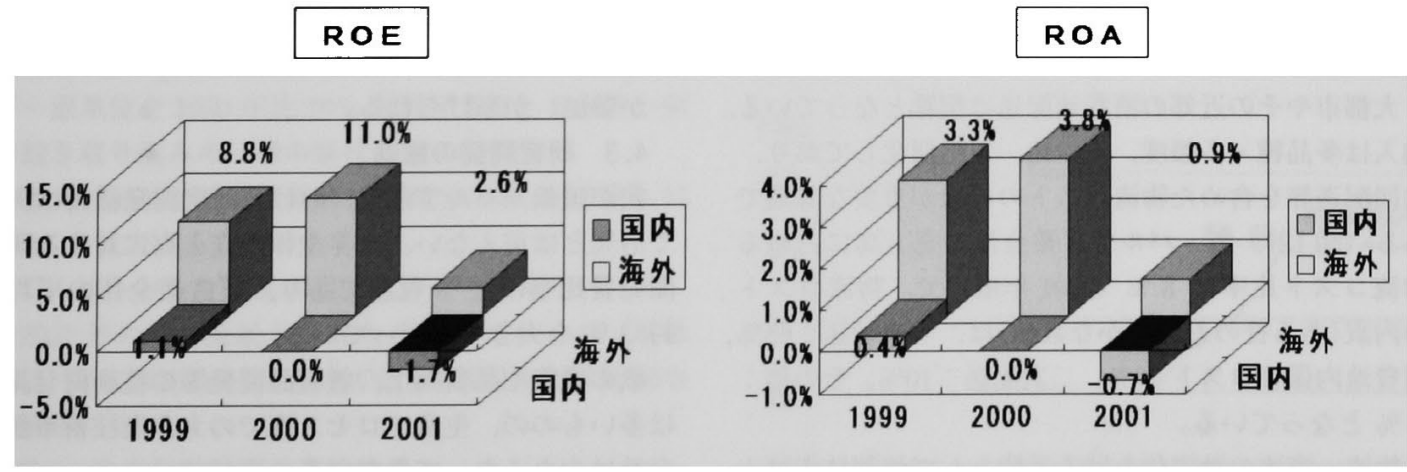

（注）国内のテータに対し、個別企莱毎に見た場合、特に退瞤給付傮務関係を補正した場合にお いては、上記指標の水準は決して低くないケースもある。

出所：有価証券報告書（国内大手 8 社/単体）、Annual Report（海外大手 3 社（IP、Stora、UPM））

国内は、2000年 $=2001$ 年3月期、1999年 $=2000$ 年3月期、1998年 $=1999$ 年3月期の数值

図 11 ROE と ROA 


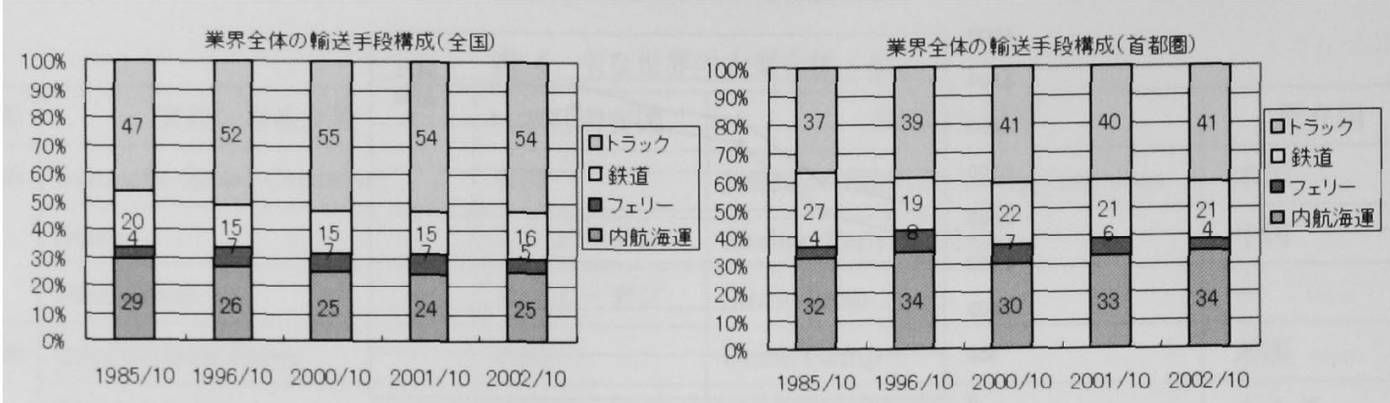

出所: 日本㡀紙連合会物流委員会

（加盟13社63工境対象，業界全体に占める生産シェアは、平成14年て約70\%)

図 12 業界全体の輸送手段構成

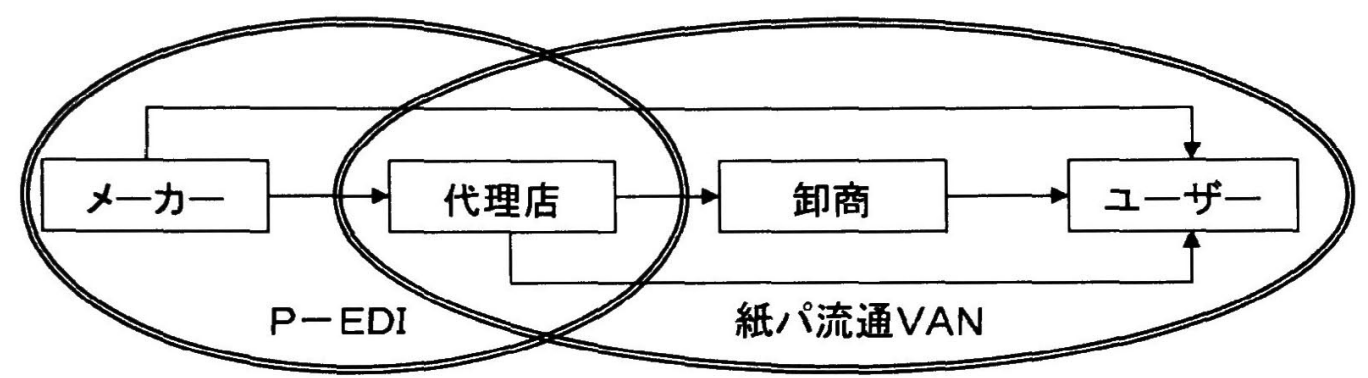

図 13 紙パルプ業界 EDI

のメルクマールとすべき。海外においてはNPV（正 味現在価値）を採用するケースが多く，そうした投資 判断基準の適正化が求められる（図 11）。

\section{2 紙・板紙の流通と情報技術}

我が国紙・パルプ産業の物流コストは, 国内他産業 や海外と比較して高水準である。

一次輸送費（生産地から消費地會庫まで搬入するま での費用)，消費地内保管コストの割合が大きく，そ の低減が重要。モータルシフトへの取り組みは, 業界 全体の動きとはなっていない。

大都市やその近郊の消費地配送は煩雑となっている。 納入は多品種・多頻度, 小口化, 短納期化しており, 共同配送等を含めた物流コストの低減が重要な課題で

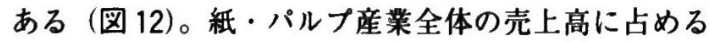
物流コスト比率は $8 \%$ （2001年度）で, 物流コスト の内訳(ある社のおおまかな数值)は, 一次輸送：65\%, 消費地内保管コスト $20 \%$, 二次配送：10\%, その他： $5 \%$ となっている。

物流，商流の効率化を図る手段として情報技術は大 きな役割を果たす。紙・パルプ産業における業界 EDI は,2つのシステムが併存する形態となっている。

情報技術に関しては，業界 EDI を有効活用し，物 流・商流の業務及び物流現場での作業効率の向上を図 っていく必要がある。 また，e-マーケットプレイスは，立ち上がり期にあ り，現状ではまだ機能していないが，その有効活用は 今後の大きな課題である。

業界 EDI としては「カミネット」がある。メーカ - ・代理店・物流業者用の「P-EDI」と代理店・卸商 ・ユーザー用の「紙パ流通VAN」から構成されてい る（実態的にはこれらが独立したシステムのように機 能している)（図 13）。

今後の課題として, P-EDI, 紙パ流通 VAN の塞質 的な統合, ユーザーの取込（現在はごく一部のユーザ 一が参加）が挙げられる。

\section{3 研究開発の推進}

我が国紙・パルプ産業における研究開発活動は決し て活発とは言えない。業界全体の売上高に対する研究 開発費比率は $1 \%$ 程度であり, 製造業全体の平均の 䄪 $3 \%$ を大きく下回っている。

紙の機能や品質向上, 新製品開発等の技術開発課題 は多いものの, 生産プロセス面での大きな技術革新の 余地は少なくなってきている。

しかしながら，低成長環境下においても活力をもっ て企業活動を継続していくためには，イノベーション を引き起こすような研究開発を推進していくことが重 要な課題である（表 5)。 
表 5 紙・パルプ産業の研究開発の状況

(単位：億円）

\begin{tabular}{l|l|r|r|r}
\hline \multicolumn{1}{c|}{ 年 } & \multicolumn{1}{c|}{ 度 } & \multicolumn{1}{c|}{1998} & \multicolumn{1}{c|}{1999} & \multicolumn{1}{c}{2000} \\
\hline 全産業 & 売上高 & $3,439,522$ & $3,473,922$ & $3,608,040$ \\
\cline { 2 - 5 } & 研究開発費 & 108,011 & 106,302 & 108,602 \\
\hdashline & 比率 & $3.14 \%$ & $3.06 \%$ & $3.01 \%$ \\
\hline 全製造業 & 売上高 & $2,521,105$ & $2,587,391$ & $2,652,973$ \\
\cline { 2 - 5 } & 研究開発費 & 98,071 & 95,216 & 98,160 \\
\cline { 2 - 5 } & 比率 & $3.89 \%$ & $3.68 \%$ & $3.70 \%$ \\
\hline 紙・パルプ産業 & 売上高 & 46,607 & 50,189 & 48,673 \\
\cline { 2 - 5 } & 研究開発費 & 522 & 532 & 477 \\
\cline { 2 - 5 } & 比率 & $1.12 \%$ & $1.06 \%$ & $0.98 \%$ \\
\hline
\end{tabular}

出所：総務省科学技術研究調査報告

表 6 ・パルプ産業の生産量及びエネルギー消費量（日米比較）

\begin{tabular}{l|c|c|c}
\hline & 日本 $(2001 \mathrm{FY})$ & 米国 $(1997 \mathrm{FY})$ & 日米比 \\
\hline 生産量 $($ チトン) & 30,352 & 86,225 & $35.2 \%$ \\
エネルギー消費量 $\left(\times 10^{6} \mathrm{MJ}\right)$ & 595,288 & $2,942,127$ & $20.2 \%$ \\
総エネルギー原単位 $(\mathrm{MJ} / \mathrm{t})$ & 19,613 & 34,121 & $57.5 \%$ \\
購入エネルギー消費量 $\left(\times 10^{6} \mathrm{MJ}\right)$ & 415,395 & $1,312,189$ & $31.7 \%$ \\
購入エネルギー原単位 $(\mathrm{MJ} / \mathrm{t})$ & 13,686 & 15,218 & $89.9 \%$ \\
\hline
\end{tabular}

\section{4 環境問題への対応}

\subsection{1 地球温暖化対策}

地球温暖化対策に関しては，我が国企業は海外と比 べても省エネルギーは進んでいる。

自主行動計画においては, 2010 年までに賱入エネル ギー原単位を 1990 年比 $10 \%$ 削娍するとしており, 引 き続き取り組みの一層の强化が求められる。

また, 2010 年までに所有・管理する植林面積を 55 万 haに拡大する計画である。

1）紙・パルプ産業の省エネルギー対策

2001 年の紙・板紙トン当たりの総エネルギー原単 位は, 1990 年比約 $91.1 \%$ まで改善 (米国に比べ約 $60 \%$ の水漸)（表 6)。

2）自主行動計画の進捗状況

省エネルギーの推進として,2010 年までに睛入エネ ルギー原単位を 1990 年比 $10 \%$ 削減することについて は, 2001 年度で 90 年比 $92.7 \%$ となっている。ただし, 前年度より $0.4 \%$ 悪化している。

植林事業の推進として, 2010 年までに植林地を 55
万 ha に拡大することについては, 2001 年末の海外植 林面皘は 30 万 ha, 国内 13 万 ha と合わせ 43 万 ha と なっている。

$\mathrm{RPF}$ の利用の促進として, 2010 年までに 60 万トン を利用することについては, 2001 年度における RPF

(\%)

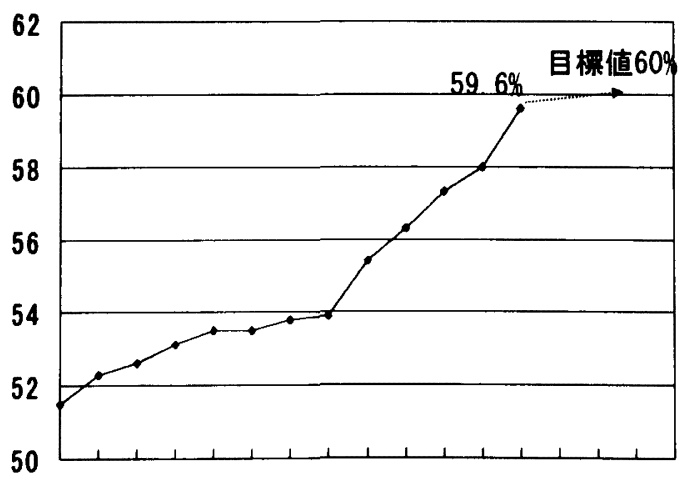

90919293949596979899011234456 図 14 我が国の古紙利用率の推移 
表 7 品種別古紙利用率 (2001 年)

(\%)

\begin{tabular}{l|c}
\hline \multicolumn{1}{c|}{ 主な品種 } & 古紙利用率 \\
\hline 紙 & 36 \\
\hline 新聞巻取紙 & 65 \\
印刷情報用紙 & 25 \\
衛生用紙 & 51 \\
\hline 板紙 & 91 \\
\hline 段ボール原紙 & 93 \\
紙器用板紙 & 79 \\
\hline 紙・板紙計 & 58 \\
\hline
\end{tabular}

表 8 古紙他用途利用量の推移

(単位 $: t$ )

\begin{tabular}{|c|c|c|c|}
\hline & 平成 11 年 & 平成 14 年 & 平成 18 年 \\
\hline 建材用フィラー & 13,750 & 42,200 & 36,000 \\
\hline 古紙ボード & 29,355 & 29,282 & 34,500 \\
\hline 料 & 4,514 & 6,107 & 8,500 \\
\hline セルローズファイバー & 7,100 & 11,100 & 13,400 \\
\hline パルプモールド & 43,323 & 47,051 & 54,688 \\
\hline 緩衝 材 & 3 & 3,066 & 3,510 \\
\hline 固形燃料 & 86,147 & 134,400 & 306,200 \\
\hline 脱 臭 剂 & 103 & 0 & 20 \\
\hline 吸 油 剤 & 21 & 27 & 90 \\
\hline 污泥脱水剂等 & 38 & 3,368 & 6,500 \\
\hline 他用途製品生産量 & 187,160 & 279,790 & 475,264 \\
\hline 古紙利用量 & 123,911 & 181,842 & 284,962 \\
\hline
\end{tabular}

※固形燃料は, RPF と RDF の合算

※平成 18 年の数値は見込み

(出典：財)古紙再生促進センター調査)

表 9 古紙他用途利用率の日米比較

\begin{tabular}{c|c|c}
\hline & 平成 10 年 & 平成 11 年 \\
\hline 日 本 & $0.7 \%$ & $0.7 \%$ \\
\hline 米 国 & $4.5 \%$ & $4.9 \%$ \\
\hline
\end{tabular}

※古秖他用途利用率 $=$ 他用途利用量 $/$ 全古紙消費量

利用量は䄪 7.8 万トンで, 更なる利用促進が必要とな っている。

\subsection{2 古紙リサイクルの推進}

古紙リサイクルについては, 2005 年度（平成 17 年 度）までに古紙利用率を $60 \%$ まで高めるという目標 を資源有効利用促進法省令で設定したところである。

我が国の古紙利用率は現状で約 $59.6 \%$ と，世界的 にも高い水準にあるが,今後はリサイクル率の低いオ フィス古紙等の利用促進が課題である（図 14,表 7)。 古紙他用途利用はほとんど進展しておらず，古紙りサ イクルを進めるにあたっては, その抜本的な取り組み が重要な課題である。米国では, 古紙の $4.9 \%$ が他用 途に利用されている（表 8,表 9）。

\section{5. 紙・パルプ産業の競争力強化の方策}

\section{1 生産効率の向上を目指した国内生産体制の 再構築}

海外からの輸入競争圧力に対抗していく観点からは,
生産効率の向上を目指した国内生産体制の再構築が必 要である。このため, 過剩設備や小规模で高齢な非効 事設備のスクラップ・集的化を進めることにより, 生 産効率の向上を図って行く必要がある。生産性の向上 のためには，真に差別化につながる製品スペックを導 入する一方で，古くなったものの整理・統合を図るこ とにより，全体として製品スペック数を削減していく ことが必要である（図 15）。

生産性・収益性の向上を図るにあたっては，その目 標設定を適切に行うとともに評価していくことが重要 である。このような指標は，各企業毎に異なるべきも のであるが, 紙・パルプ産業全体の参考值としては， 紙・パルブ産業を取り巻く状況等を考慮した場合, ROAで 3.0\%を当面の目標とすることが試算される。

(参考) 紙・パルプ産業全体での ROA 目標数値 $3.0 \%$ の考え方について

1）目標数值は各企業毎に当然異なるべきものであ るが、紙・パルブ産業全体での参考值を提案したもの。 


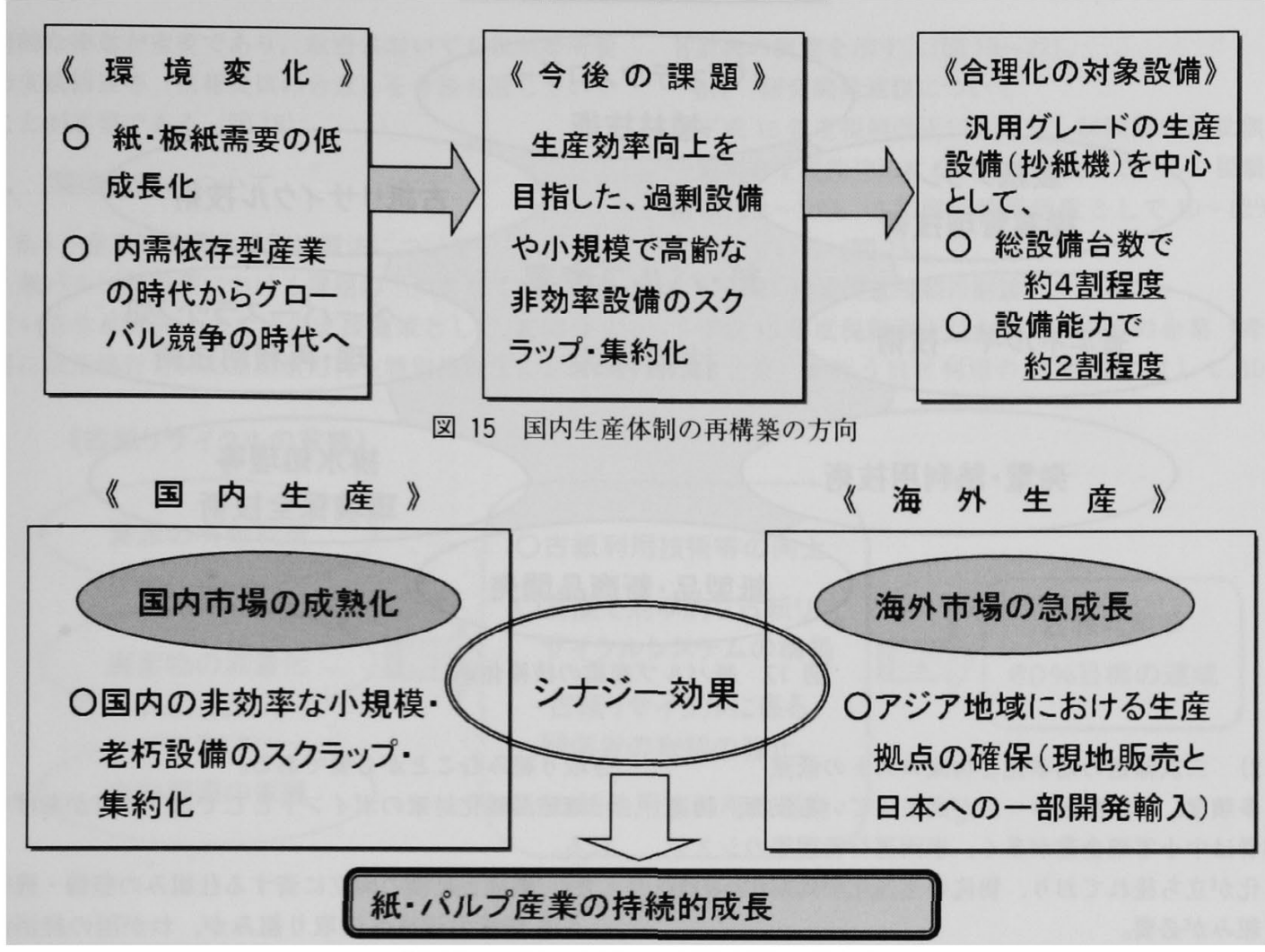

図 16 アジア市場への国際展開の考え方

2）数值目標の設定にあたっては，以下の前提条件 等を勘案。

(1) 株主資本コストを $6.5 \%$, 負債コストを $2 \%$ と仮定。

(2) 株主資本・負債比率に関しては, D/Eレシオ を 1 と仮定。

(3)以上により加重平均資本コストを $3.8 \%$ とした。 (加重平均資本コスト

$=2 \times(1-0.42) \times 1 / 2+6.5 \times 1 / 2=3.8 \%)$

(4) 総資本に対する投下資本の割合は，ここでは， 平均的な数值である $80 \%$ を採用。

以上から, ROA 目標値を $3.0 \%$ とした $(3.8 \times 0.8$ $=3.0 \%$ )。

\section{2 アジア市場の動向を踏まえた国際展開}

我が国紙・パルプ産業が欧米大手企業に対抗して事 業規模の拡大を図るためには，市場の急成長が見込ま れるアジア地域でのビジネスチャンスを活かすことが 重要な選択肢である。

我が国紙・パルプ企業は, 海外企業との連携等, 様々 な形でアジア諸国における生産拠点の確保を進めるこ とも重要である。
こうしたアジア展開にあたっては，現地販売とわか 国人の一部開発輸入を組み合わせることにより，国内 の非効率・老朽設備のスクラップ・集約化を行うなど の国内生産体制の再構築を進める上での「シナジー効 果」が期待できる（図 16）。

\section{3 物流の効率化と情報技術の活用}

物流コスト低減のために，一次輸送費，消費地内保 管・配送コストの低減等が重要である。そのため, 共 同輸送の拡大, 大型 RORO 船の導入等によるモータ ルシフトの推進が必要である。こうした物流の効率化 を進める上で，阻害要因となっている制度面の問題の 改善も重要である。

物流効率化を図るためには情報技術の活用も有効で あり，EDIの活用や，コードの改良などによる EDI の高機能化のための取り組みも重要である。

物流・流通効率化の実現のための取り組み課題は以 下のとおりである。

1）情報インフラの整備と EDI 化の推進

サプライチェーン上での重複業務を排除し，物流・ 商流の事務業務及び作業効率の向上を図るため, 情報 インフラの整備と EDI の活用を図ることが必要。 


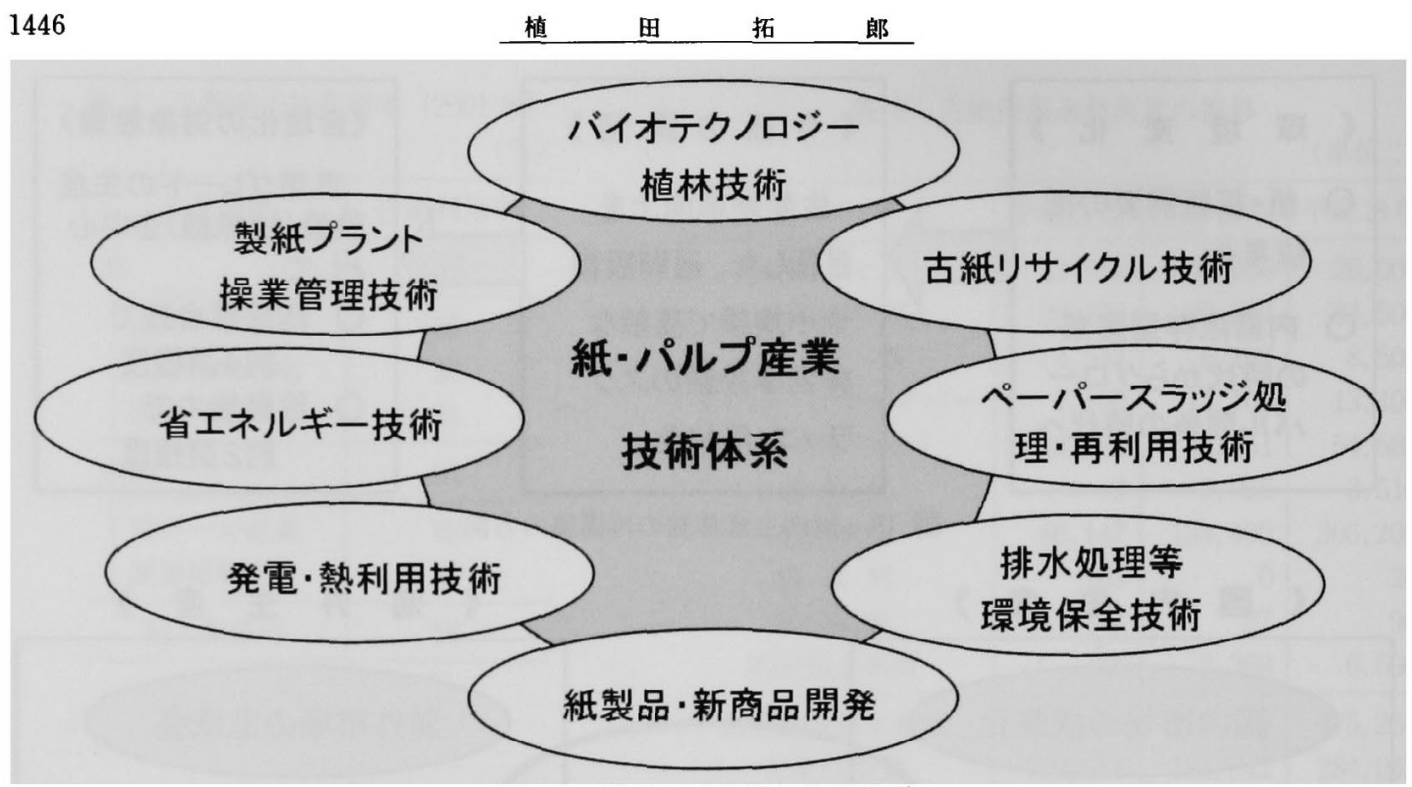

図 17 紙パルプ産業の技術体系

2）二次輸送の効率化と物流コストの低減

多頻度, 小口配送ニーズが高まっている反面, 物流 業者は中小零細企業が多く，車両運行管理等のシステ 厶化が立ち後れており, 物流の迅速化や効率化への取 り組みが必要。

3）物流・流通の高コスト体質の改善

多様化する顧客ニース対応により, 物流・商流コス トが增大しており，経営体質強化及び競争力強化のた めには，効率的な物流システムを構築することが必要。

\section{4 研究開発の推進}

紙・パルプ産業が持つ技術力を最大限に発揮し，バ イオテクノロジーなどの先端技術を植林や生産プロセ スに活用したり，製品分野において，新たな需要の創 出につながるイノペーションを生み出すような研究開 発を推進することが重要である(図 17)。

こうした研究開発活動の推進にあたっては, 実用化 開発補助金制度や産学連携による研究開発制度等の活 用が有効である。

また, 平成 15 年度税制改正において, 政府は,こ うした研究開発活動の促進策として, 研究開発費総額 を対象とする滅税措置を導入したところである。

\section{5 環境問題への対応}

わが国紙・パルプ産業の環境対策は既に相当の取り 組みがなされており，その对策の水準の高さは国際競 争を行う上での強みとも位置付けられる。

地球温暖化対策については, 自主行動計画で示され た，睡入エネルギー原単位を 2010 年で 1990 年比 $10 \%$ 削減することを目標に，省エネルギー对策等に引き続
き取り組みむことが必要である。

地球温暖化对策のポイントとして以下の点があげら れる。

1）環境と経済の両立に資する仕組みの整備・構築 $6 \%$ 削減の達成への取り組みが, わが国の経済活 性化にもつながるような仕組みの整備・棈筑を図る。

2） ステップ・バイ・ステップのアプローチ

第 1 ステップ (2002〜2004 年)，第 2 ステップ (2005 〜2007 年)，第 3 ステップ（2008～2012 年）の前に対 策の進捗状況・排出状況等を評価し，必要な追加的対 策・施策を段階的に講じていく。

3）自主的取り組みの着実な実施とフォローアップ

4）革新的な環境・エネルギー技術の研究開発の強 化

5）国民一人一人のライフスタイルの変革

6) 国際的連携の確保

7） 京都メカニズムの活用

京都議定書の約束を費用効果的に達成するためには， 京都メカニズム（CDM, JI 及び排出量取引）の活用 を適切に行っていくことが重要である。

古紙リサイクルについては, 2005 年度（平成 17 年 度）までに古紙利用率を $60 \%$ まで高めるという目標 の達成へ向けた取り組みを進めることが必要である。

目標達成に向けて, 古紙利用促進行動計画に沿った 関係者の連携・協力が重要。古秖利用率向上には特に 印刷情報用紙等オフィス古紙のリサイクルの推進が需 要である。

紙 to 紙のリサイクルに加え, 古紙他用途利用の本 
格的な推進が重要であり, 政府においても税制等所要 の支援措置等（情報提供の合意）を今後も講じていく ことが必要である(図 18)。

\section{6. 関連施策について}

\section{1 産業活力再生特別措置法について}

紙パルプ製造業における課題の一つとして挙げられ ている生産性向上のための支援施策として, 2003 年 4 月に改正施行された産業活力再生特別措置法における
各計画の概要を示す。(図 19〜22)。

6.2 研究開発減税について

平成 15 年度税制改正において, 試験研究費総額の 一定割合を税額控除する制度を創設している。税額控 除率は 8〜 10\%（3年間の時限措置として 10〜 $12 \% ）$ となっている (図 23)。

\subsection{IT 投資促進税制の創設}

平成 15 年度税制改正において, 全ての企業（青色 申告企業）が行う自社利用のIT投資に対して, $10 \%$

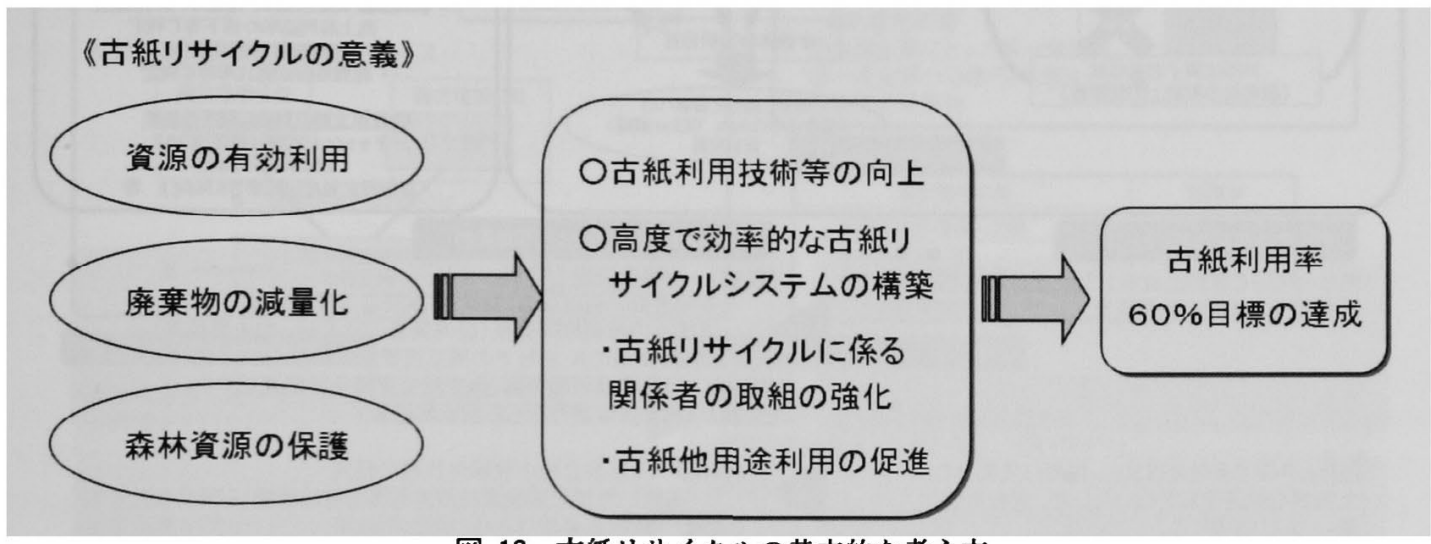

図 18 古紙リサイクルの基本的な考え方

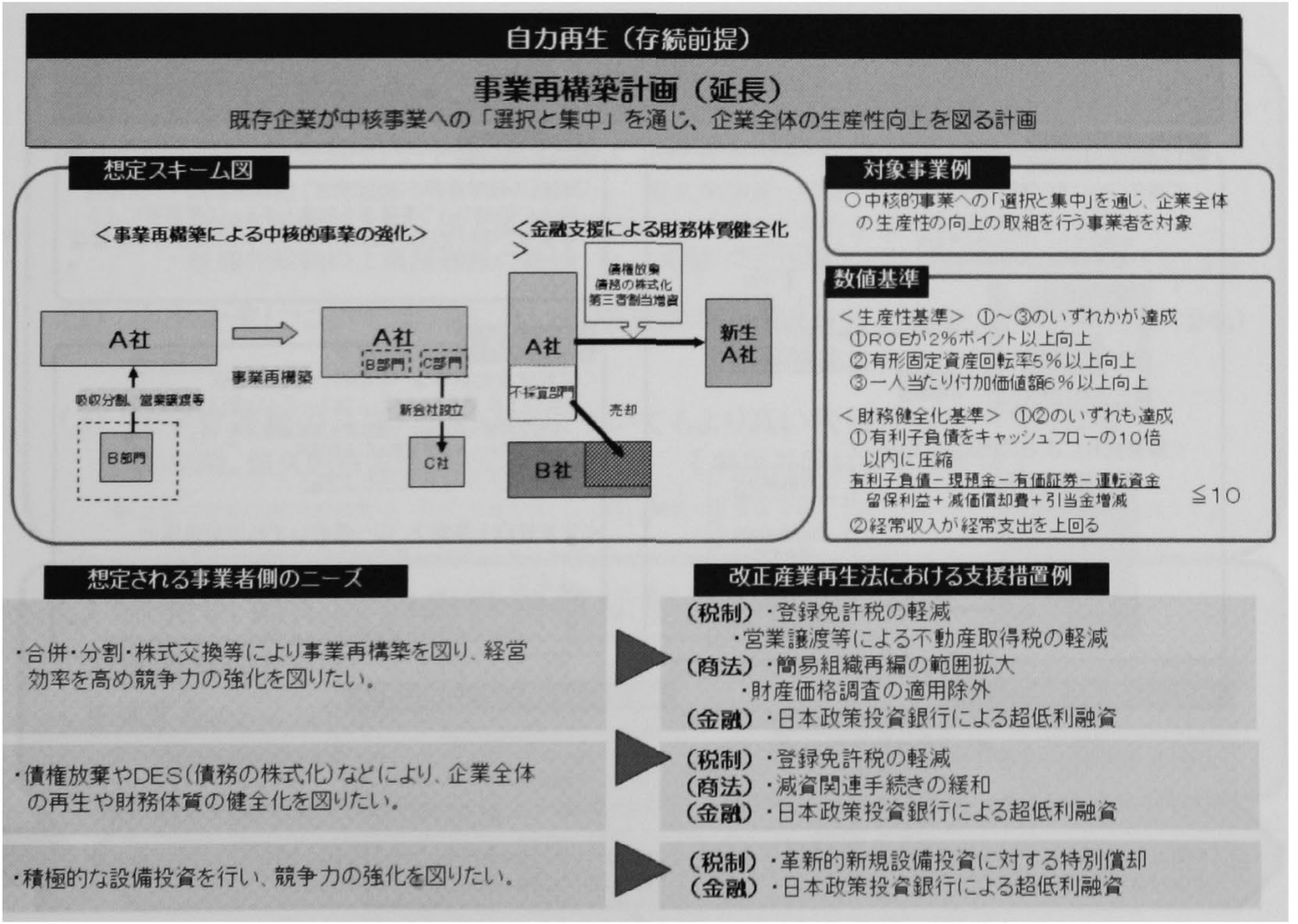

図 19 改正産業活力再生特別措置法における各訃画の概要(1) 


植田拓郎

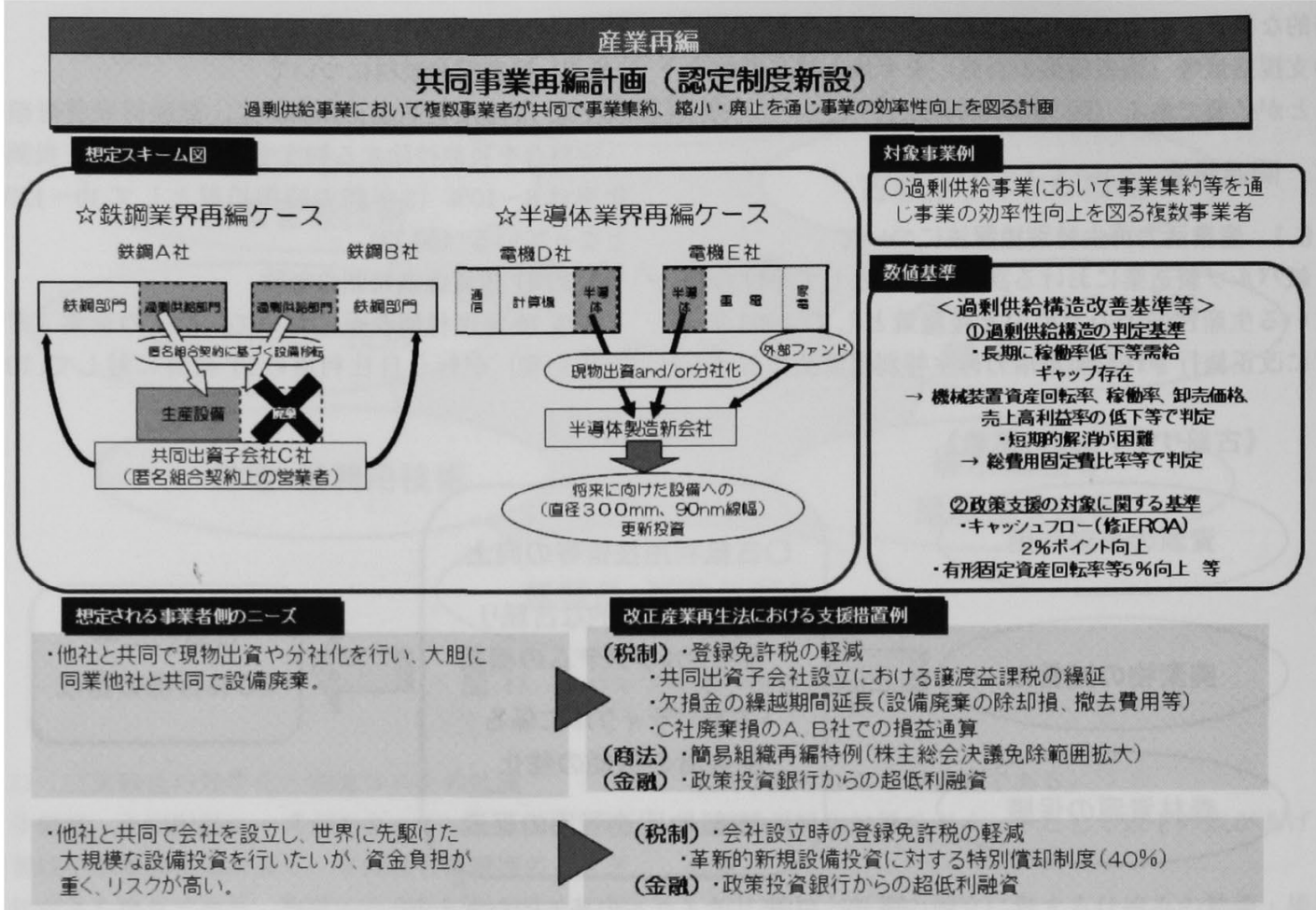

図 20 改正産業活力再生特別措置法における各計画の概要(2)

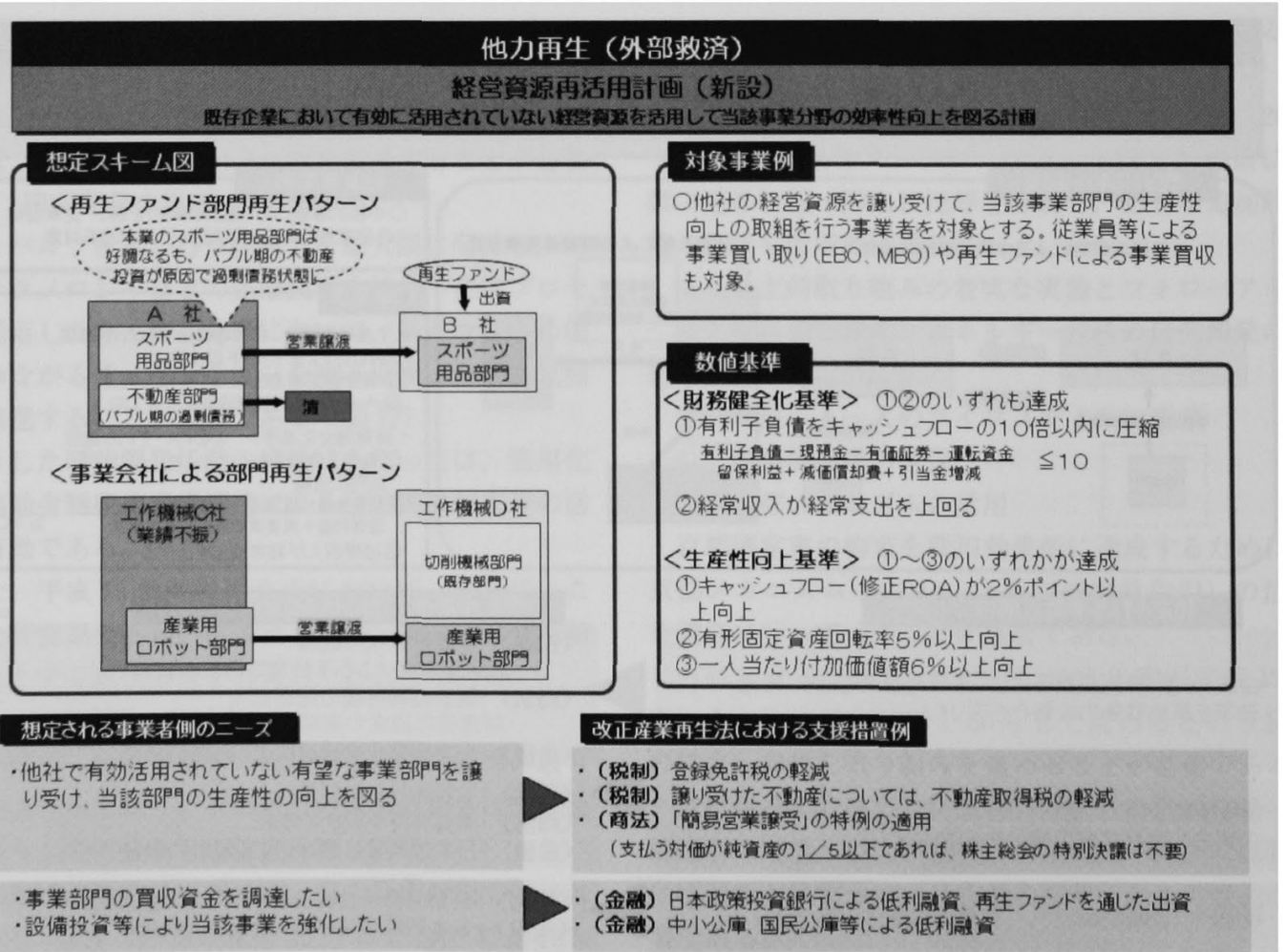

図 21 改正産業活力再生特別措䈯法における各計画の概要(3) 
国内空洞化への対床

事業革新設備導入計画（新設）

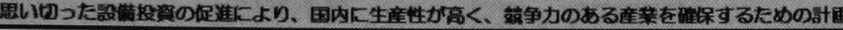

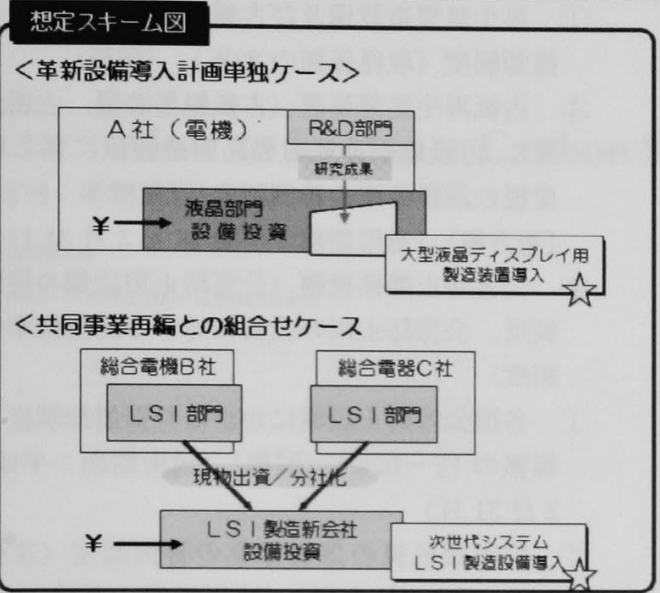

\section{対象事業例}

自社技術を活用して開発した革新設備を導入し、事業 部門の生産性改善を図る取組

\section{訆定基準}

〈高付加価值拠点化基準〉

(1)研究開発機能との有機的な連携が認められる

(2)全くの新製品の製造設備又は徒来比 $40 \%$ 以上 の生産性改善

(3)当該企業にとって第一号投盗

(4)一定金䫑 $(1$ ○億円)を超える投資

(5)設備の革新性

\section{各計画每の特別偳却率}

\begin{tabular}{|c|c|}
\hline 各㣌画の名称 & 特價率 \\
\hline 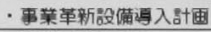 & $24 \%$ \\
\hline 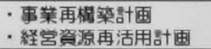 & $30 \%$ \\
\hline ·共国事美再編計面 & $40 \%$ \\
\hline
\end{tabular}

\section{想定される事業者側の}

・革新的製造工程を導入するに当たり，税制上の優 遇措置を受けたい

\section{改正産業再生法におけする支援措置例}

\section{(税制)}

·取得価額の一定割合の特別僙却を認める

(事業革新設備導入計画の場合、特侻率24\%)

・革新設備の導入等のための資金を調達したい (金融)

·盗金調達を円滑に行いたい、

·日本政策投資銀行からの融盗(高付加価值拠点化支援融盗制度) ・産業基盤整備基金による債務保証 (保証限度額:原則50億円)

図 22 改正産業活力再生特別措置法における各計画の概要 $(4)$

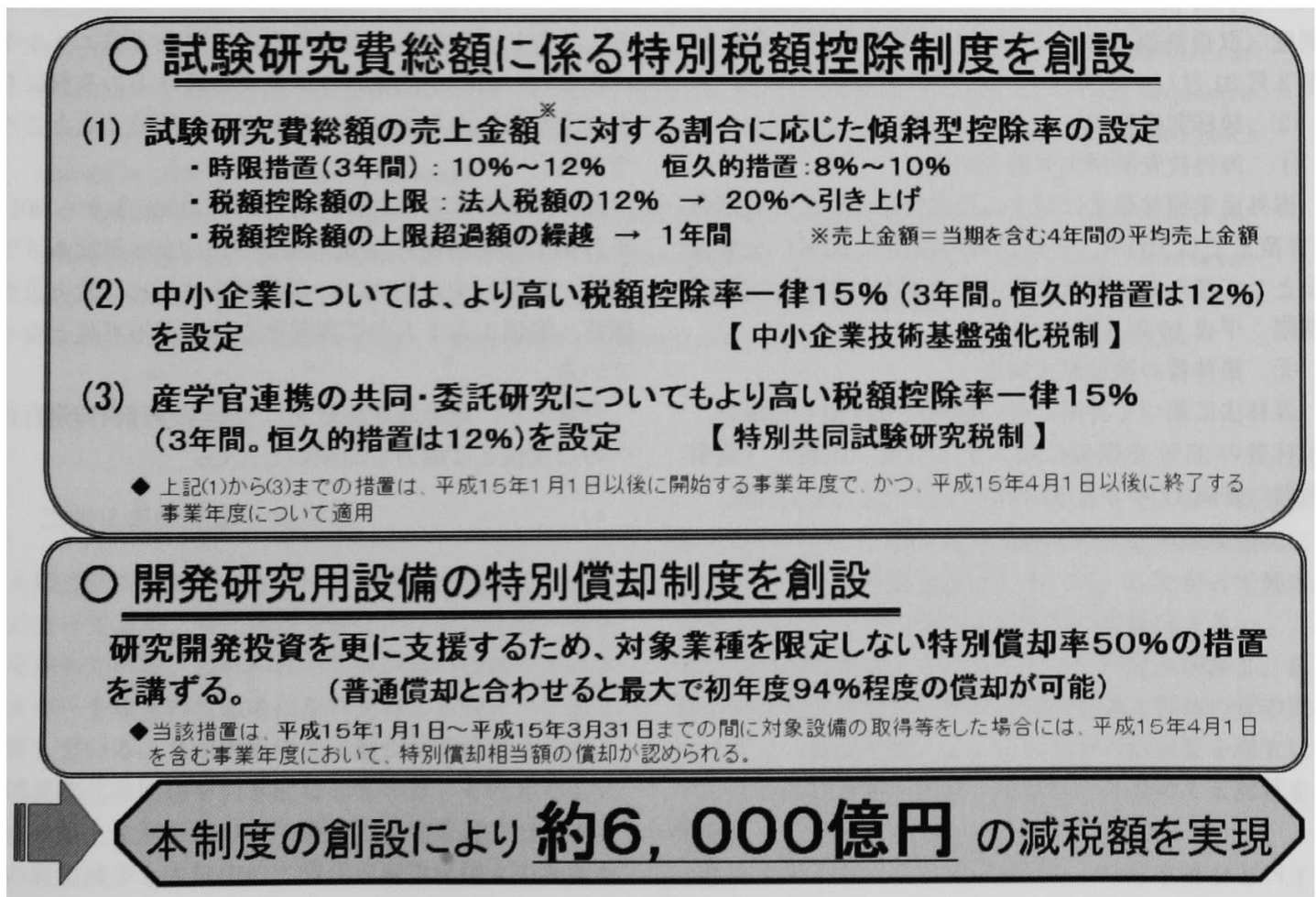

図 23 研究開発税制の抜本強化 


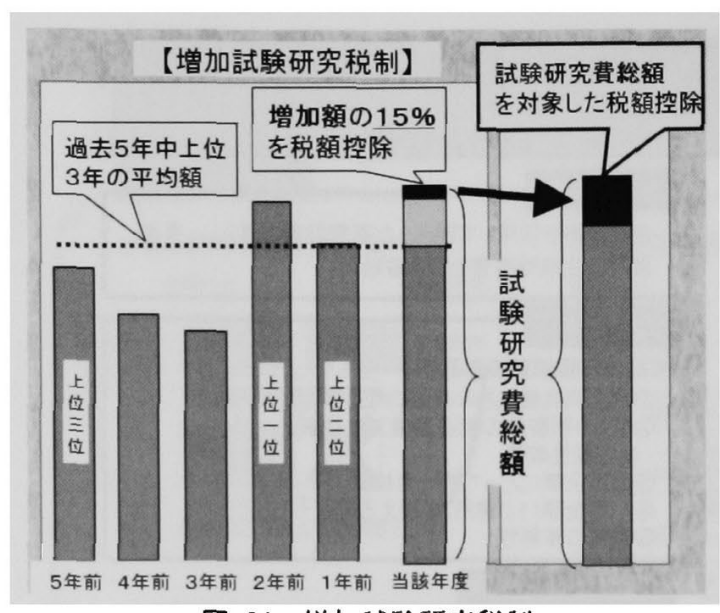

図 24 增加試験研究税制

の税額抂除と取得資産の $50 \%$ の特別償却の選択を認 める制度を創設。IT 投資の加速に向けた重点的な施 策投入を行う (法人税額の $20 \%$ を上限, 超過分は一 年分綝越し可能である)。

\section{4 製紙産業関連税制について}

製紙産業関連税制としては次のとおり。

(1) 省エネルギー設備導入促進税制（エネルギー需 給構造改革投資促進税制)

エネルギー有効利用製造設備 8 設備に係る特別償却 制度（取得価額の $30 \%$ ）(国税）（適用期限：平成 16 年 3 月 31 日)。

2. 植林関係税制

(1) 海外投資等損失染備金制度

海外産業植林事業に対する投融資について一定割合 （育苗までは $100 \%$ ，それ以降の段階は $30 \%$ ）を準備 金として積み立て損金に算入する制度（国税）（適用 期限：平成 16 年 3 月 31 日)。

2. 植林费の損金算入制度

森林法に基づく計画に従い植林費を支出した場合， 植林費の $35 \%$ を損金に算入する制度（国税）（適用 期限：平成 17 年 3 月 31 日)。
（3）リサイクル関連税制（再商品化設備の特別償却 制度, 廃率物再生処理用設備に対する課税標準の 特例制度)

(1) 再生紙製造設備及び古紙再生ボードに係る特別 償却制度（取得価額の $23 \% ） （$ 国税）

(2) 古紙再生処理装置（古紙脱墨装置，古紙漂白装 置)，古紙他用途利用製品製造装置に係る固定資 産税の課税標準の特例制度 (課税標準：2/3 3/4) (地方税)（適用期限：平成 16 年 3 月 31 日）

（4）公害防止関係税制（公害防止用設備の特別償却 制度，公害防止用の設備に対する課税標準の特例 制度)

(1) 各種公害防止設備にかかる特別償却制度（取得 価額の 12 16\%）（国税）（適用期限：平成 17 年 3 月 31 日)

(2) 固定資産税の課税標準の特例制度（課税標準 $1 / 6 \sim 5 / 6$ ）（地方税）（適用期限：平成 16 年 3 月 31 日)

\section{6. さいごに}

エネルギー多消費産業である紙パルプ産業において， 地球温暖化対策の実施や推進は重要な課題である。一 方，最近の景気の低迷による収养悪化などにより，環 境対策への投資余力への悪影響が憝念される状況にあ る。しかし，これらへの取り組みは更なる省エネルギ 一化といった我が国紙パルプ産業の競争力の基盤にも なりうることから，一層の取り組みを期待するところ である。

我が国における京都議定書の約束 (2008 年から 2012 年の第 1 約束期間に温室効果ガスを 1990 年比・ $6 \%$ 削减）を履行するために，産業界をはじめ，地方公共 団体，国民 1 人 1 人のご理解とご協力が不可欠となっ ている。

今後とも, 地球温暖化対策について, 経済産業行政 へのご支援とご協力をお願いしたい。 
地球温暖化対策一20 世紀後半異常社会からの脱却

\author{
埼玉大学経渚学部 外岡
}

20 世紀後半は巨大資本のビジネス競争により世界的な大量消费がなされ世界的な資源の枯渴と環境 の破壊を招いた。オソン層破丧、気候変動，化学物質污染など地球史的にも異常体験といえる時代であ った。持続可能的発展と簡単に言うが 20 世紀後半の延長上には持続可能社会への入り口さえ見つから ないであろう。持続可能社会への再出発点として 3 千年紀の人類社会の方向性を考え, 20 世紀後半の異 常性を再確認して 21 世紀前半の日本のあり方を考える。地球温暖化問题はその再出発への合図となる。

(本文 2 ベージ)

\title{
地球温暖化問題と課題
}

経済産業省 製造産業局 紙業生活文化用品課 植田 拓郎

1997 年 12 月に京都で開催された気候変動势組条約第 3 回締約国会議（COP 3）において採択された 「京都議定著」の約束を果たすため，エネルギー多消费産業である紙・パルブ産業の地球温暖化対策へ の取り組みは重要な課題である。しかしながら，最近の景気低迷による企業収益悪化の影製を受け，即 境対策に対する投資が䔡念される状況にある。そのため，紙・パルブ産業においても環境問題に対処す るだけでなく産莱竸争力を強化することが不可欠である。このような我が国紙・パルフ産業を取り巻く 状況を乗り越えていくためにも，紙・バルブ産業の現状と直面する課題を十分に認識しておく必要があ る。以上の钼点から, 地球温暖化問題に関する政府の取り組み, 紙・パルフ産業の現状と課題, 産業竸 争力強化に向けた方策なとについて逨べる。

(本文 14 ベージ)

\section{森林の二酸化炭素吸収の考え方}

\section{日本林莱技街協会 藤森 隆郎}

森林生態系の二酸化炭素の吸収と貯藏によって, 大気中の二酸化炭素港度の縟和を図ることは大きな 意味を持つ。炭素の吸収促進と宸素の眝藏量を最大に近い值に持っていくことはどちらも重要であるが, 同じ林分で而者を同時に達成することはできない。炭素の吸収速度と貯藏量は林分の発達段階によって 変化し，吸収速度は若峆段陼で，眝藏量は老峆段階で最大值に達する。

したがって吸収量を高めるためには，若龄段陵の後期から成熟段階の前期ぐらいまでを目標林型とし， 眝蔵量を高めるためには老跲段陼を目標林型にすべきである。前者を達成することは木材生産のための 森林管理と同調し，後者を達成することは生物多様性や水土保全など環境保全のための森林管理と同調 する。したがって管理目標に応した目榎林型を流域に配置する森林計画の実践が重要である。

木材を加工するために要するエネルギー量は他の物兵材料を加工するために要するエネルギー量より 少ないので, 持続可能な木材生産を前提とした木材の利用促進は, 化石エネルギーの使用削減に連なる。 また，木材（廃材を含めて）をエネルキーとして使うことは，その分化石エネルキーの使用量削減に連 なり，大気中の二酸化炭素縟和策として大きな意味を持つ。

(本文 33 ベージ) 